Prepared in cooperation with the ALABAMA DEPARTMENT OF TRANSPORTATION

\title{
Simulations of Flooding on Pea River and Whitewater Creek in the Vicinity of the Proposed Elba Bypass at Elba, Alabama
}

U.S. GEOLOGICAL SURVEY

Water-Resources Investigations Report 02-4258

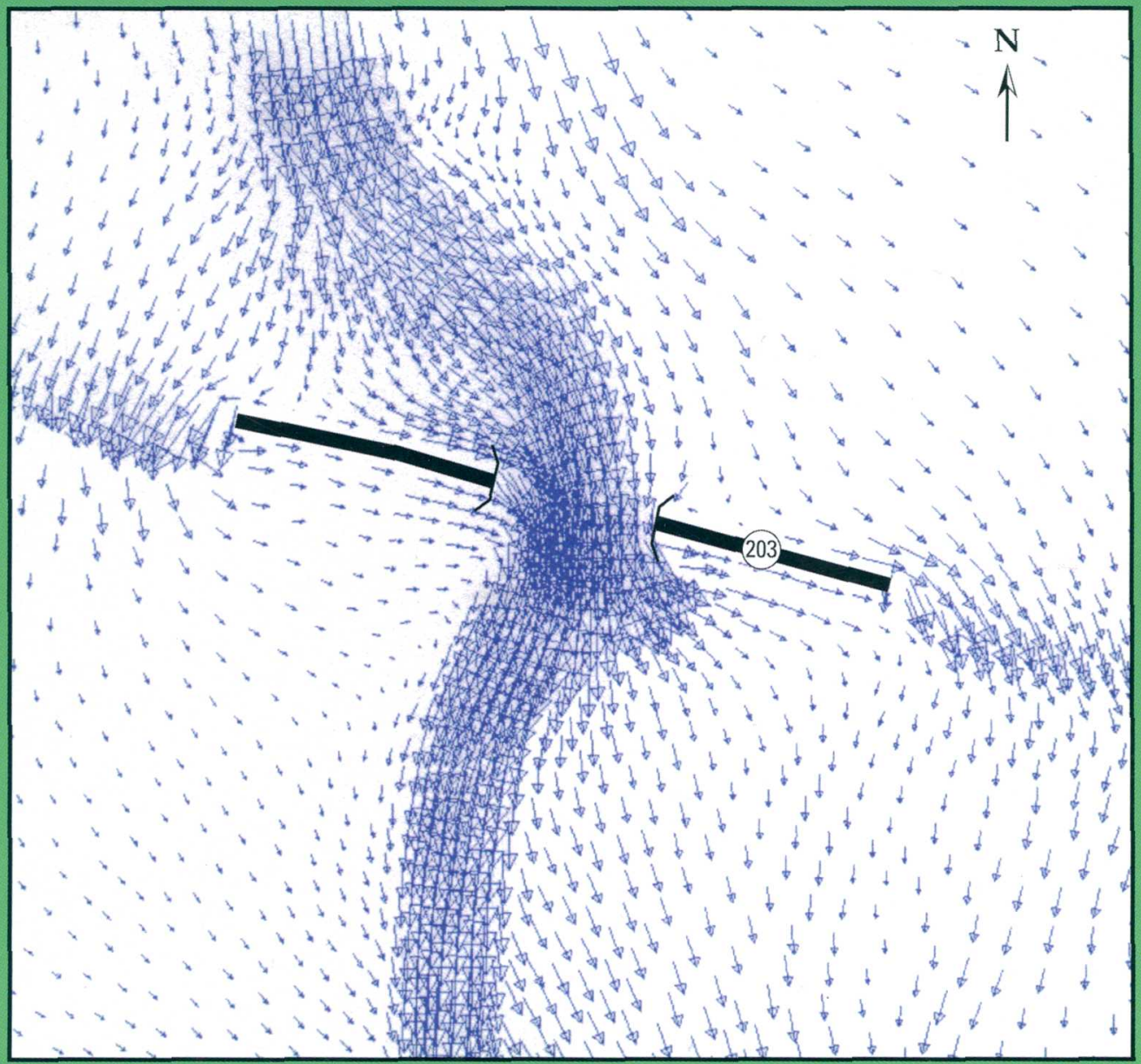





\section{Simulations of Flooding on Pea River and Whitewater Creek in the Vicinity of the Proposed Elba Bypass at Elba, Alabama}

By T.S. Hedgecock

U.S. GEOLOGICAL SURVEY

Water-Resources Investigations Report 02-4258

Prepared in cooperation with the

ALABAMA DEPARTMENT OF TRANSPORTATION 


\title{
U.S. DEPARTMENT OF THE INTERIOR
}

\section{GALE A. NORTON, Secretary}

\author{
U.S. GEOLOGICAL SURVEY
}

CHARLES G. GROAT, Director

The use of firm, trade, and brand names in this report is for identification purposes only and does not constitute endorsement by the U.S. Geological Survey.

For additional information write to:

Copies of this report can be purchased from:

District Chief

U.S. Geological Survey

2350 Fairlane Drive, Suite 120

Montgomery, AL 36116

dc_al@usgs.gov
U.S. Geological Survey

Branch of Information Services

Box 25286, Federal Center

Denver, C0 80225

1-888-ASK-USGS 


\section{CONTENTS}

Abstract …1...

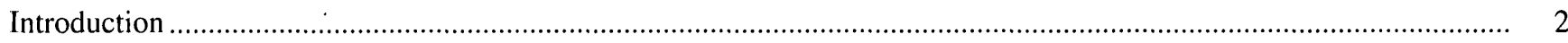

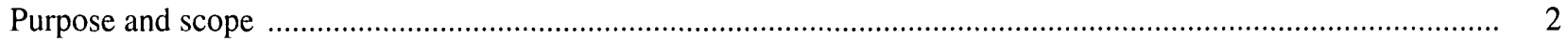

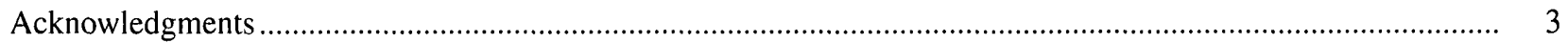

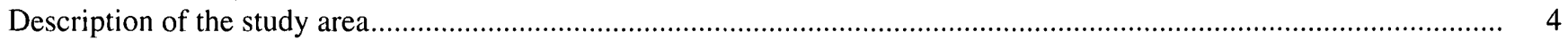

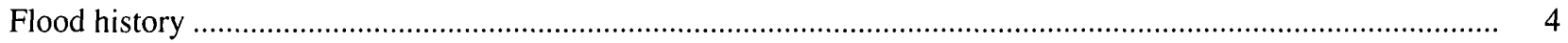

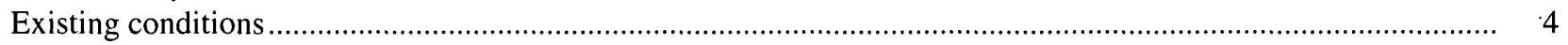

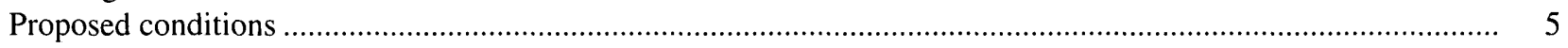

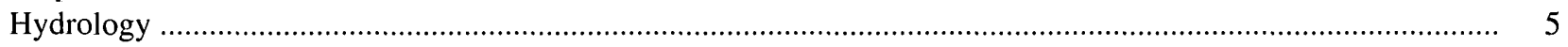

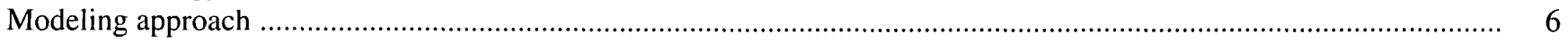

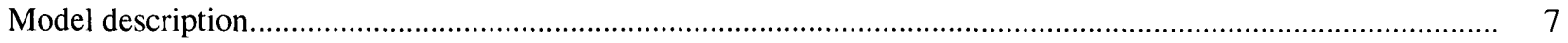

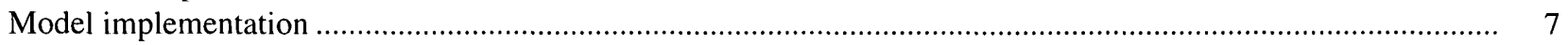

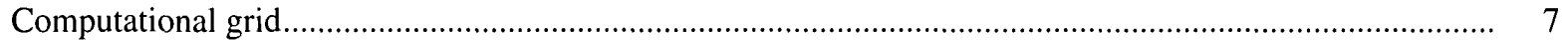

Boundary conditions …................................................................................................................ 8

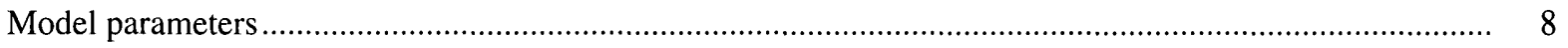

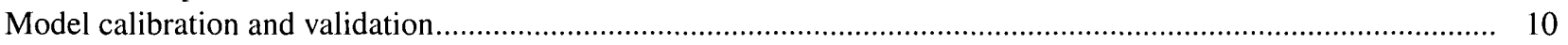

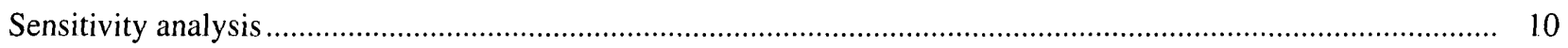

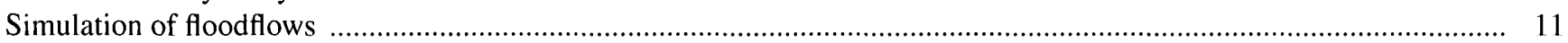

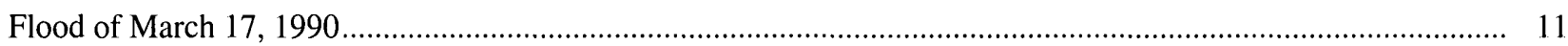

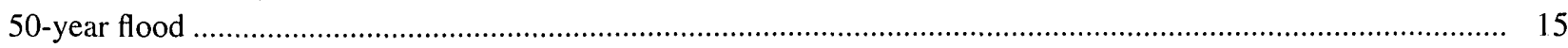

Existing conditions

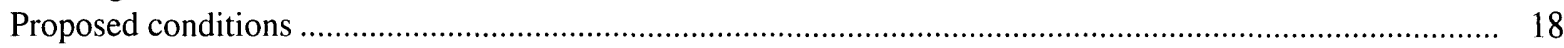

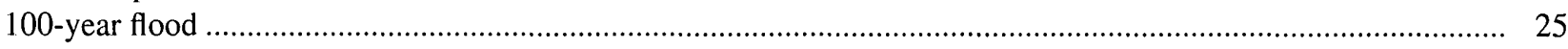

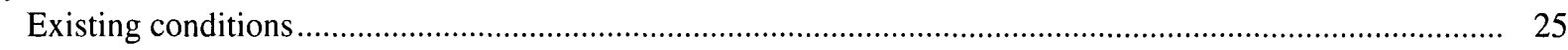

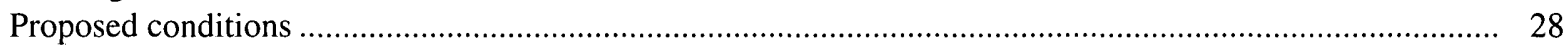

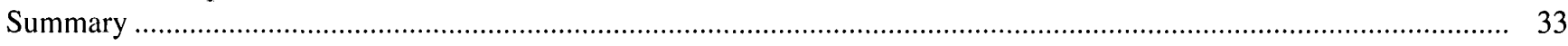

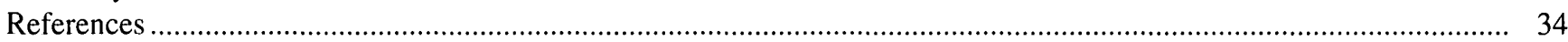

\section{FIGURES}

1. Map showing Pea River and Whitewater Creek study reach, Elba, Coffee County, Alabama ............................. 3

2-27. Plots showing:

2. Discharge hydrographs for Pea River and Whitewater Creek for March 1990 flood, Elba, Alabama............ 5

3. Land-surface elevations for Pea River and Whitewater Creek study reach ............................................... 6

4. Finite-element grid used in flow simulations for existing conditions ....................................................... 7

5. Finite-element grid used in flow simulations for proposed conditions ..................................................... 8

6. Manning's roughness coefficients used for simulation of March 1990 flood .............................................. 9

7. Manning's roughness coefficients used for simulations of existing and proposed conditions ....................... 10

8. Computed water-suface elevations for March 1990 flood .................................................................. 12

9. Computed velocity contours for March 1990 flood ............................................................................ 13

10. Computed velocity contours for March 1990 flood for existing State Highway 203 bridge crossing............ 14

11. Computed velocity vectors for March 1990 flood for existing State Highway 203 bridge crossing.............. 15

12. Computed water-surface elevations for 50 -year flood for existing conditions .......................................... 16

13. Computed velocity contours for 50 -year flood for existing conditions ............................................... 17

14. Computed velocity contours for 50-year flood for existing State Highway 203 bridge crossing ................... 18

15. Computed water-surface elevations for 50 -year flood for proposed conditions ........................................ 20

16. Computed velocity contours for 50 -year flood for proposed conditions .................................................. 21

17. Computed velocity contours for 50-year flood for proposed bridge crossing of Whitewater Creek ............... 22

18. Computed velocity contours for 50-year flood for proposed bridge crossing of Pea River .......................... 23

19. Computed velocity vectors for 50-year flood for proposed bridge crossing of Whitewater Creek ................ 24

20. Computed velocity vectors for 50 -year flood for proposed bridge crossing of Pea River............................... 25 
21. Computed water-surface elevations for 100 -year flood for existing conditions.......................................... 26

22. Computed velocity contours for 100 -year flood for existing conditions ..................................................... 27

23. Computed velocity contours for 100-year flood for existing State Highway 203 bridge crossing ................. 28

24. Computed water-surface elevations for 100 -year flood for proposed conditions.......................................... 30

25. Computed velocity contours for 100 -year flood for proposed conditions................................................... 31

26. Computed velocity contours for 100-year flood for proposed bridge crossing of Whitewater Creek............. 32

27. Computed velocity contours for 100-year flood for proposed bridge crossing of Pea River ......................... 33

\section{TABLES}

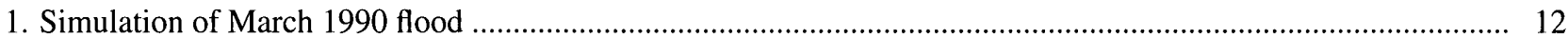

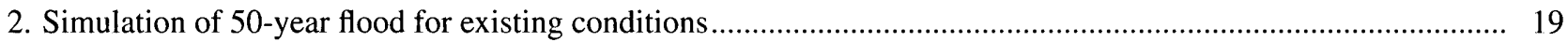

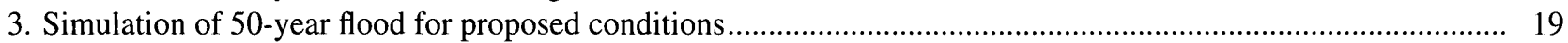

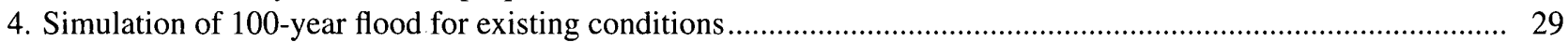

5. Simulation of 100-year flood for proposed conditions ................................................................................. 29

\section{CONVERSION FACTORS, VERTICAL AND HORIZONTAL DATA, AND} ACRONYMS/ABBREVIATIONS

\begin{tabular}{rll}
\hline Multiply & By & To obtain \\
foot $(\mathrm{ft})$ & Length & \\
mile $(\mathrm{mi})$ & 0.3048 & meter $(\mathrm{m})$ \\
& 1.609 & kilometer $(\mathrm{km})$ \\
& Area & \\
square mile $\left(\mathrm{mi}^{2}\right)$ & 2.590 & square kilometer $\left(\mathrm{km}^{2}\right)$ \\
& Flow & \\
foot per mile $(\mathrm{ft} / \mathrm{mi})$ & 0.1894 & meter per kilometer $(\mathrm{m} / \mathrm{km})$ \\
foot per second $(\mathrm{ft} / \mathrm{s})$ & 0.3048 & meter per second $(\mathrm{m} / \mathrm{s})$ \\
square foot per second $\left(\mathrm{ft}^{2} / \mathrm{s}\right)$ & 0.0929 & square meter per second $\left(\mathrm{m}^{2} / \mathrm{s}\right)$ \\
cubic foot per second $\left(\mathrm{ft}^{3} / \mathrm{s}\right)$ & 0.02832 & cubic meter per second $\left(\mathrm{m}^{3} / \mathrm{s}\right)$ \\
\hline
\end{tabular}

Data:

Vertical coordinate information is referenced to the North American Vertical Datum of 1988 (NAVD 88).

Horizontal coordinate information is referenced to the North American Datum of 1983 (NAD 83).

Acronyms/Abbreviations:

ALDOT

FEMI

FESWMS-2DH

GRIDGEN

USACE

USGS

WSPRO
Alabama Department of Transportation software package used to construct the computational grids Finite Element Surface-Water Modeling System for Two-Dimensional Flow in the Horizontal Plane automated grid generator U.S. Army Corps of Engineers U.S. Geological Survey a one-dimensional step-backwater model used for computing water-surface profiles 


\title{
SIMULATIONS OF FLOODING ON PEA RIVER AND WHITEWATER CREEK IN THE VICINITY OF THE PROPOSED ELBA BYPASS AT ELBA, ALABAMA
}

\author{
By T.S. Hedgecock
}

\section{ABSTRACT}

A two-dimensional finite-element surface-water model was used to study the effects of proposed modifications to the State Highway 203 corridor (proposed Elba Bypass/relocated U.S. Highway 84) on water-surface elevations and flow distributions during flooding in the Pea River and Whitewater Creek Basins at Elba, Coffee County, Alabama. Flooding was first simulated for the March 17, 1990, flood, using the 1990 flood-plain conditions to calibrate the model to match measured data collected by the U.S. Geological Survey and the U.S. Army Corps of Engineers after the flood. After model calibration, the effects of flooding were simulated for four scenarios: (1) floods having the 50- and 100-year recurrence intervals for the existing flood-plain, bridge, highway, and levee conditions; (2) floods having the 50- and 100-year recurrence intervals for the existing flood-plain and levee conditions with the State Highway 203 embankment and bridge removed; (3) floods having the 50- and 100 -year recurrence intervals for the existing floodplain, bridge, and highway conditions with proposed modifications (elevating) to the levee; and (4) floods having the 50- and 100-year recurrence intervals for the proposed conditions reflecting the Elba Bypass and modified levee.

The simulation of floodflow for the Pea River and Whitewater Creek flood of March 17, 1990, in the study reach compared closely to flood profile data obtained after the flood. The flood of March 17, 1990, had an estimated peak discharge of 58,000 cubic feet per second at the gage (just below the confluence) and was estimated to be between a 50-year and 100-year flood event. The estimated peak discharge for Pea River and Whitewater Creek was 40,000 and 42,000 cubic feet per second, respectively.
Simulation of floodflows for the 50-year flood (51,400 cubic feet per second) at the gage for existing flood-plain, bridge, highway, and levee conditions indicated that about 31 percent of the peak flow was conveyed by the State Highway 203 bridge over Whitewater Creek, approximately 12 percent overtopped the State Highway 203 embankment, and about 57 percent was conveyed by the Pea River flood plain east of State Highway 125. For this simulation, flow from Pea River (2,380 cubic feet per second) overtopped State Highway 125 and crossed over into the Whitewater Creek flood plain north of State Highway 203 , creating one common flood plain. The watersurface elevation estimated at the downstream side of the State Highway 203 bridge crossing Whitewater Creek was 202.82 feet. The girders for both the State Highway 203 and U.S. Highway 84 bridges were partially submerged, but U.S. Highway 84 was not overtopped.

For the 100-year flood $(63,500$ cubic feet per second) at the gage, the simulation indicated that about 25 percent of the peak flow was conveyed by the State Highway 203 bridge over Whitewater Creek, approximately 24 percent overtopped the State Highway 203 embankment, and about 51 percent was conveyed by the Pea River flood plain east of State Highway 125 . The existing levee adjacent to Whitewater Creek was overtopped by a flow of 3,200 cubic feet per second during the 100-year flood. For this simulation, flow from Pea River (6,710 cubic feet per second) overtopped State Highway 125 and crossed over into the Whitewater Creek flood plain north of State Highway 203. The water-surface elevation estimated at the downstream side of the State Highway 203 bridge crossing Whitewater Creek was 205.60 feet. The girders for both the State Highway 203 and U.S. Highway 84 
bridges were partially submerged, and the west end of the U.S. Highway 84 bridge was overtopped.

Simulation of floodflows for the 50-year flood at the gage for existing flood-plain and levee conditions, but with the State Highway 203 embankment and bridge removed, yielded a lower water-surface elevation (202.90 feet) upstream of this bridge than that computed for the existing conditions. For the 100-year flood, the simulation indicated that removing the State Highway 203 embankment and bridge lowered the upstream stage about 0.07 foot.

Simulation of floodflows for the 50-year flood at the gage for existing flood-plain, bridge, and highway conditions, with proposed modifications (increased crest elevation) to the levee, yielded the same watersurface elevations as those for the existing conditions. The 50-year flood did not overtop the existing levee and, therefore, would not overtop a taller one. For the 100year flood, the simulation indicated that elevating the levee increased the upstream stage about 0.7 foot in the vicinity of State Highway 203.

Simulation of floodflows for the 50-year flood at the gage for the proposed conditions indicated that about 43 percent of the peak flow was conveyed by the proposed bridge over Whitewater Creek, approximately 52 percent by the proposed main channel bridge over Pea River, and about 5 percent by the proposed relief bridge for Pea River. For this simulation, flow from Pea River (1,220 cubic feet per second) overtopped State Highway 125 and crossed over into the Whitewater Creek flood plain north of the proposed bypass. The water-surface elevation estimated at the downstream side of the proposed bridge crossing Whitewater Creek was 202.77 feet, whereas the watersurface elevation estimated at the downstream side of the proposed main channel bridge over Pea River was 203.06 feet. No overtopping of the proposed bypass occurred; however, the girders of the U.S. Highway 84 bridge were partially submerged.

For the 100-year flood, the simulation indicated that about 46 percent of the peak flow was conveyed by the proposed bridge over Whitewater Creek, approximately 47 percent by the proposed main channel bridge over Pea River, and about 7 percent by the proposed relief bridge for Pea River. For this simulation, flow from Pea River (3,990 cubic feet per second) overtopped State Highway 125 and crossed over into the Whitewater Creek flood plain north of the proposed bypass. The water-surface elevation estimated at the downstream side of the proposed bridge crossing Whitewater Creek was 206.54 feet, whereas the water- surface elevation estimated at the downstream side of the proposed main channel bridge crossing Pea River was 206.63 feet. No overtopping of the proposed bypass occurred; however, the west end of the U.S. Highway 84 bridge was overtopped. The girders of the proposed Whitewater Creek bridge and the proposed main channel bridge over Pea River were partially submerged.

\section{INTRODUCTION}

The hydraulic performance of bridges during floods is a major concern when the opening and grade of drainage structures are designed. In the case of multiple bridge openings, it is important to know the distribution of discharge through the bridges for an efficient hydraulic design. The Alabama Department of Transportation (ALDOT) plans to expand State Highway 203 (fig. 1) to a four-lane highway, and extend this corridor eastward to U.S. Highway 84 to form the Elba Bypass [Project Number NHF-91(16)]. The Elba Bypass (fig. 1) will be a divided highway with eastbound and westbound lanes crossing the Pea River and Whitewater Creek flood plains. The bypass will consist of three dual-bridge openings-one channel bridge for each lane over Whitewater Creek and one channel and one relief bridge for each lane over Pea River. During a large flood event, floodflows from Pea River and Whitewater Creek combine into one common flood plain upstream of the proposed bypass (as was the case in 1990). This combining of floodflows greatly increases the uncertainty of the distribution of flow approaching the proposed bridges of the new bypass. Because of the complexity of this site and the two-dimensional nature of the flow, a two-dimensional flow model will best serve to determine the effects of the proposed Elba Bypass on flooding. During 2001-2002, the U.S. Geological Survey (USGS), in cooperation with the ALDOT, analyzed the flood hydraulics of the Pea River and Whitewater Creek crossings of the proposed Elba Bypass. This study will serve as an aid to other States and municipalities that encounter complex flow hydraulics near bridges.

\section{Purpose and Scope}

This report presents results of simulated floods having 50-year and 100-year recurrence intervals for both the existing and proposed conditions, as well as results of the simulated March 17, 1990, flood, which was used for calibration purposes. Discharge, discharge distribution, water-surface elevation, backwater, and velocity data are 


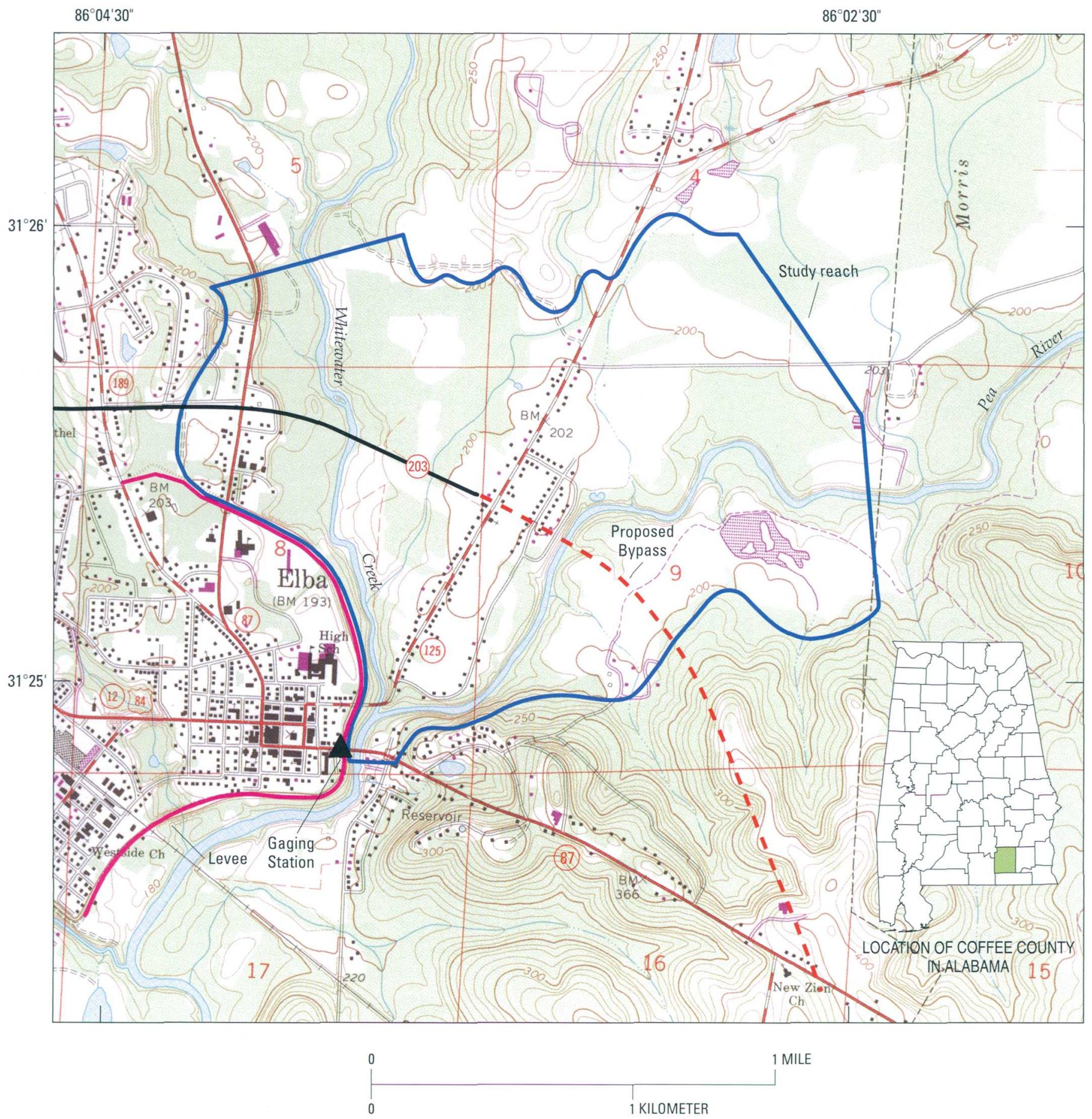

Figure 1. Pea River and Whitewater Creek study reach, Elba, Coffee County, Alabama.

given for various locations of interest throughout the study reach. Other topics discussed include: evaluation of hydrology, collection of survey data, development of a computational grid, selection of a flow model, calibration of the model, model sensitivity, and simulation of floodflows.

\section{Acknowledgments}

The assistance of Mr. Tom Flournoy, ALDOT Hydraulic Engineer, and personnel of the Seventh Division of the ALDOT is greatly appreciated. Also, special thanks is given to Mses. Kristin Justice and 
Kathryn Green, engineering students, for their contributions to this study and assistance in the preparation of this report.

\section{DESCRIPTION OF THE STUDY AREA}

The study reach is located in west-central Coffee County (fig. 1) at Elba, Alabama. Pea River drains $959 \mathrm{mi}^{2}$ at U.S. Highway 84 (Pearman and others, 2001). The USGS has operated a gaging station $(02364000$ Pea River at Elba; fig. 1) at this crossing since 1930. The study reach includes approximately a 2-mi reach of the Pea River flood plain, extending from about $500 \mathrm{ft}$ downstream of the U.S. Highway 84 crossing to a point about $5,000 \mathrm{ft}$ upstream of the proposed bypass crossing. The reach also includes approximately a $1.2-\mathrm{mi}$ reach of the Whitewater Creek flood plain, extending from its mouth to a point about 2,500 ft upstream of the State Highway 203 crossing. Whitewater Creek drains $317 \mathrm{mi}^{2}$ at its mouth. The width of the Pea River flood plain ranges from about $1 \mathrm{mi}$ at the upstream end of the study reach to just under $800 \mathrm{ft}$ at the downstream end of the study reach. Pea River flows in a southwesterly direction from the northeastern end of the study reach toward the existing U.S. Highway 84 crossing. The width of the Whitewater Creek flood plain ranges from about $2,500 \mathrm{ft}$ at the upstream end of the study reach to about $500 \mathrm{ft}$ near its confluence with Pea River. Whitewater Creek flows in a south-southeasterly direction from the north-

northwestern end of the study reach toward its confluence with Pea River.

The average slope of the Pea River and Whitewater Creek Basins in the study reach is about $2.5 \mathrm{ft} / \mathrm{mi}$. The Pea River and Whitewater Creek flood plains are characterized as flat, mostly wooded land with moderate to heavy vegetative undergrowth. A small percentage of the flood plain in the study reach is farm land used for row crops, livestock, and pine tree plantations. There are also some residential areas in both flood plains in which tree cover and vegetation are minimal. The channels for Pea River and Whitewater Creek are well defined, clear, and vary in width from 100 to $150 \mathrm{ft}$. Both streams are classified as medium-width, perennial streams.

\section{Flood History}

The town of Elba has experienced five major floods on Pea River since 1929. These flood events occurred in 1929, 1975, 1990, 1994, and 1998. In most of these flood events, Whitewater Creek floodflow contributed significantly to the overall flooding that occurred on Pea River in the vicinity of Elba. The flood of March 15, 1929, had an estimated peak discharge of $68,000 \mathrm{ft}^{3} / \mathrm{s}$ at the gage and is the highest known flood to have affected Elba. At the peak, the flood of March 15, 1929, almost completely inundated the town. In 1938, a levee was constructed around the town of Elba and served as adequate protection from flooding until March 1990. Since 1990, the town of Elba has incurred millions of dollars in damages and experienced loss of life due to the three recent floods. In the floods of March 1990, July 1994, and March 1998, the existing levee was either overtopped or flanked by floodwaters. In each of these floods, overtopping of the State Highway 203 embankment occurred.

\section{Existing Conditions}

State Highway 203 is a two-lane highway with northbound and southbound lanes that cross the Whitewater Creek flood plain at an average angle (skew) of about 30 degrees (fig. 1). This crossing consists of one main channel bridge that is approximately $315 \mathrm{ft}$ long. The existing bridge opening has spillthrough-type abutments, sloping embankments, and no wingwalls. A major contraction of the flood plain occurs downstream from this crossing due to the presence of an artificial levee. This contraction begins on the west end of the flood plain about $1,400 \mathrm{ft}$ downstream from the State Highway 203 embankment and extends past the downstream end of the study reach. The degree of contraction increases in the downstream direction reaching a maximum at the U.S. Highway 84 crossing of Pea River. This contraction increases and controls water-surface elevations throughout the reach during high floodflows. The levee is earthen in type and is approximately level from one end to the other. The existing levee has an approximate crest elevation of $205 \mathrm{ft}$.

U.S. Highway 84 is a two-lane highway that crosses the Pea River flood plain at an average angle (skew) of about 0 degrees (fig. 1). This crossing consists of one main channel bridge that is approximately $690 \mathrm{ft}$ long. The existing bridge opening has spillthrough-type abutments, sloping embankments, and no wingwalls. State Highway 87 (on the west side of the study reach) and State Highway 125 (in the center of the study reach) parallel the floodflows from Pea River and Whitewater Creek. Both of these highways have very little effect on flooding since they are at ground level (no fill). 


\section{Proposed Conditions}

The ALDOT plans to replace the existing bridge at the State Highway 203 crossing of Whitewater Creek and convert the existing road to a four-lane divided highway. Proposed plans extend this corridor eastward from State Highway 125 across the Pea River flood plain and connect it to U.S. Highway 84 to form the Elba Bypass (fig. 1). There are plans for construction of both a main channel bridge and a relief bridge across the Pea River flood plain. Each of the proposed bridge openings will have spillthrough-type abutments, sloping embankments, and no wingwalls. The proposed bridge lengths are $520 \mathrm{ft}$ for the Whitewater Creek bridge, $530 \mathrm{ft}$ for the main channel bridge over Pea River, and $200 \mathrm{ft}$ for the relief bridge on the east overbank of the Pea River flood plain. On the east end of the main channel bridge over Pea River, a 125-ft guide bank will be constructed on the upstream side of the bridge. Also, the U.S. Army Corps of Engineers (USACE) plans to rebuild the levee surrounding Elba. Proposed plans are to increase the crest elevation of the levee by 5 to $7.5 \mathrm{ft}$. The crest of the proposed levee will be constructed to an elevation of $210 \mathrm{ft}$ at U.S. Highway 84 and will be built on a positive grade in the upstream direction. The design crest elevation near the northernmost extent of the levee (near State Highway 87) is $212.5 \mathrm{ft}$.

\section{Hydrology}

Flood frequencies in the Pea River and Whitewater Creek Basins were estimated by using techniques outlined in "Magnitude and Frequency of Floods in Alabama" (Atkins, 1996) and gaging station data recorded at the Pea River gage at U.S. Highway 84. Discharge hydrographs, needed for the distribution of upstream boundary inflows, were computed using techniques outlined in "Estimating Flood Hydrographs and Volumes for Alabama Streams" (Olin, 1988). For the March 17, 1990, calibration flood, theoretical lagtimes were altered for each stream to produce individual hydrographs that yielded a best-fit composite hydrograph for combined flooding at the gage (fig. 2). This composite hydrograph compared within reason to the recorded hydrograph. The estimated flood-peak discharges, upstream of their confluence, for the 1990 flood were $40,000 \mathrm{ft}^{3} / \mathrm{s}$ for Pea River and $42,000 \mathrm{ft}^{3} / \mathrm{s}$ for Whitewater Creek. These estimates were obtained by using a plot of drainage area and peak discharge per square mile for the March 1990 flood for 13 gaging stations in the general vicinity. The peak discharge at the gage was $58,000 \mathrm{ft}^{3} / \mathrm{s}$. At the time of the peak at the gage (lagtime of 52 hours), the estimated inflows were $19,000 \mathrm{ft}^{3} / \mathrm{s}$ for Pea River and $39,000 \mathrm{ft}^{3} / \mathrm{s}$ for Whitewater Creek.

Flood-peak discharges for floods having 50- and 100-year recurrence intervals were estimated for both streams above their confluence and were also estimated at the gaging station (below confluence). Since the basin

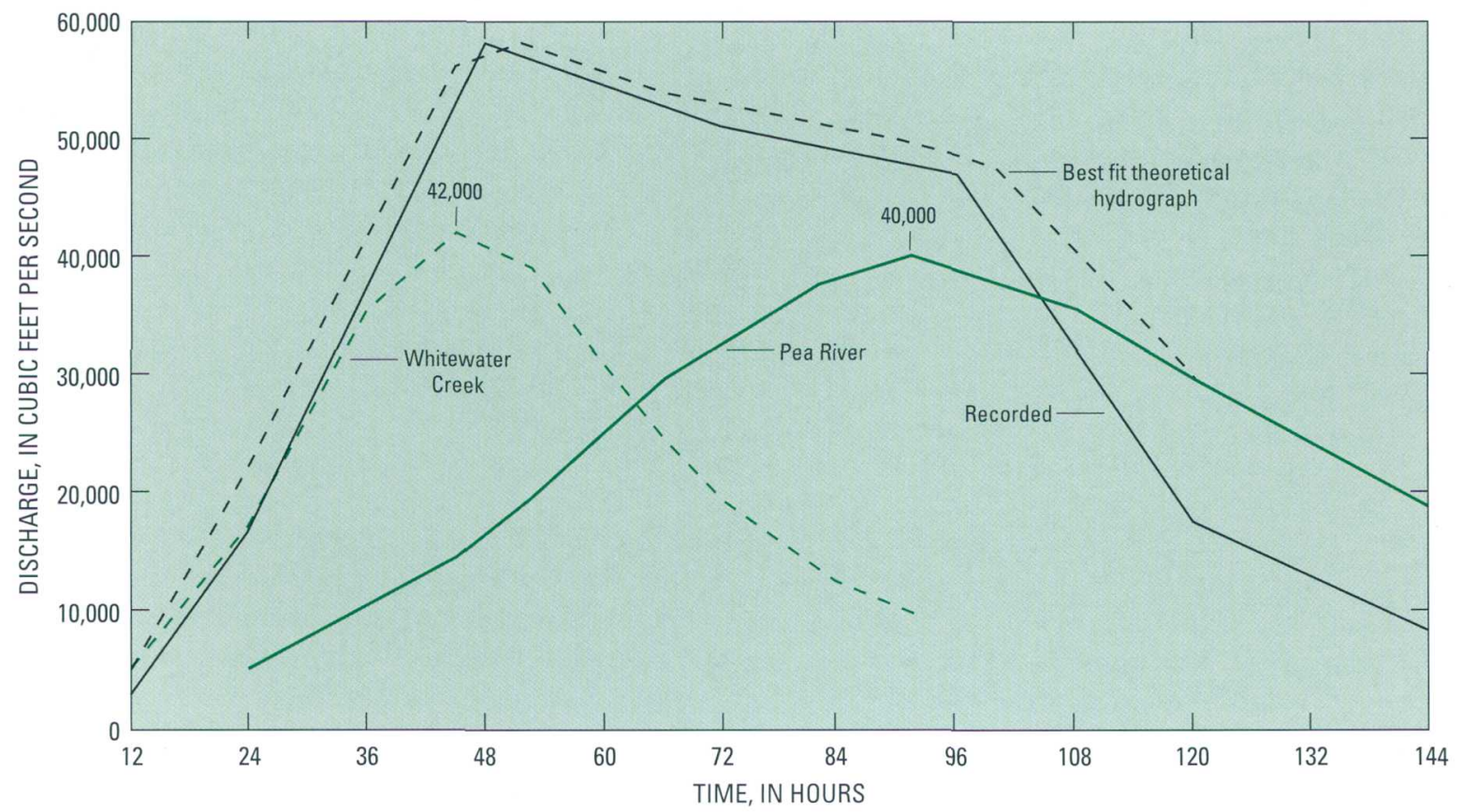

Figure 2. Discharge hydrographs for Pea River and Whitewater Creek for March 1990 flood, Elba, Alabama. 
size of Pea River is just over two times that of Whitewater Creek, theoretical lagtimes and discharge hydrographs were computed for both streams (Olin, 1988). For each recurrence interval, three hydrologic scenarios were evaluated: (1) combined peak discharge at the gage, (2) peak discharge occurring on Pea River, and (3) peak discharge occurring on Whitewater Creek. Since scenarios 2 and 3 yielded lower water-surface elevations and lower point velocities compared to scenario 1, these scenarios are not documented in this report. The peak discharges used for the 50- and 100-year floods at the gage were $51,400 \mathrm{ft}^{3} / \mathrm{s}$ and $63,500 \mathrm{ft}^{3} / \mathrm{s}$, respectively. The peak discharges used for Pea River inflow at its upstream boundary were $31,700 \mathrm{ft}^{3} / \mathrm{s}$ and $39,300 \mathrm{ft}^{3} / \mathrm{s}$ for the 50- and 100-year floods, respectively. The peak discharges used for Whitewater Creek inflow at its upstream boundary were $19,700 \mathrm{ft}^{3} / \mathrm{s}$ and $24,200 \mathrm{ft}^{3} / \mathrm{s}$ for the 50- and 100-year floods, respectively.

When Whitewater Creek is the principal source of floodflows, the observed lagtime at the gage has ranged between 40 and 50 hours. When Pea River is the principal source of floodflows, the observed lagtime at the gage has ranged between 100 and 110 hours. For the 50- and 100year floodflows, a theoretical lagtime of 72 hours was used for the composite peak at the gage. This lagtime represents an average of observed conditions at the gage. Floodflows from unnamed tributaries in the study reach were ignored due to the small relative size of these streams as compared to Pea River and Whitewater Creek. Because of the large magnitudes of the floods simulated, the large contributing drainage areas, and the relatively short study reach, sustained peak discharges are probable; therefore, steady-flow conditions were simulated.

\section{MODELING APPROACH}

Floodflow simulations for the study were based on a two-dimensional finiteelement surface-water model. First, a computational grid representing the flow system for the existing conditions was constructed using an automated grid generator, digital topographic data (E. Christy, Alabama Department of Transportation, written commun., 2001), and flood-plain cross sections surveyed by personnel of the Seventh Division of the ALDOT during the summer of 2001. This grid then was used as input into the two-dimensional finite-element flow model, and simulations were performed for the peak of March 17, 1990, the 50-year flood, and the 100-year flood. This process was repeated for the 50- and 100-year floodflows for a scenario that removed the existing Highway 203 bridge and embankment. Another scenario simulated the existing conditions including the proposed modifications to the levee. Finally, simulations were performed for the 50- and 100-year floods for the proposed conditions, reflecting both the Elba Bypass and modified levee. Land-surface elevation contours for the study reach are shown in figure 3 .

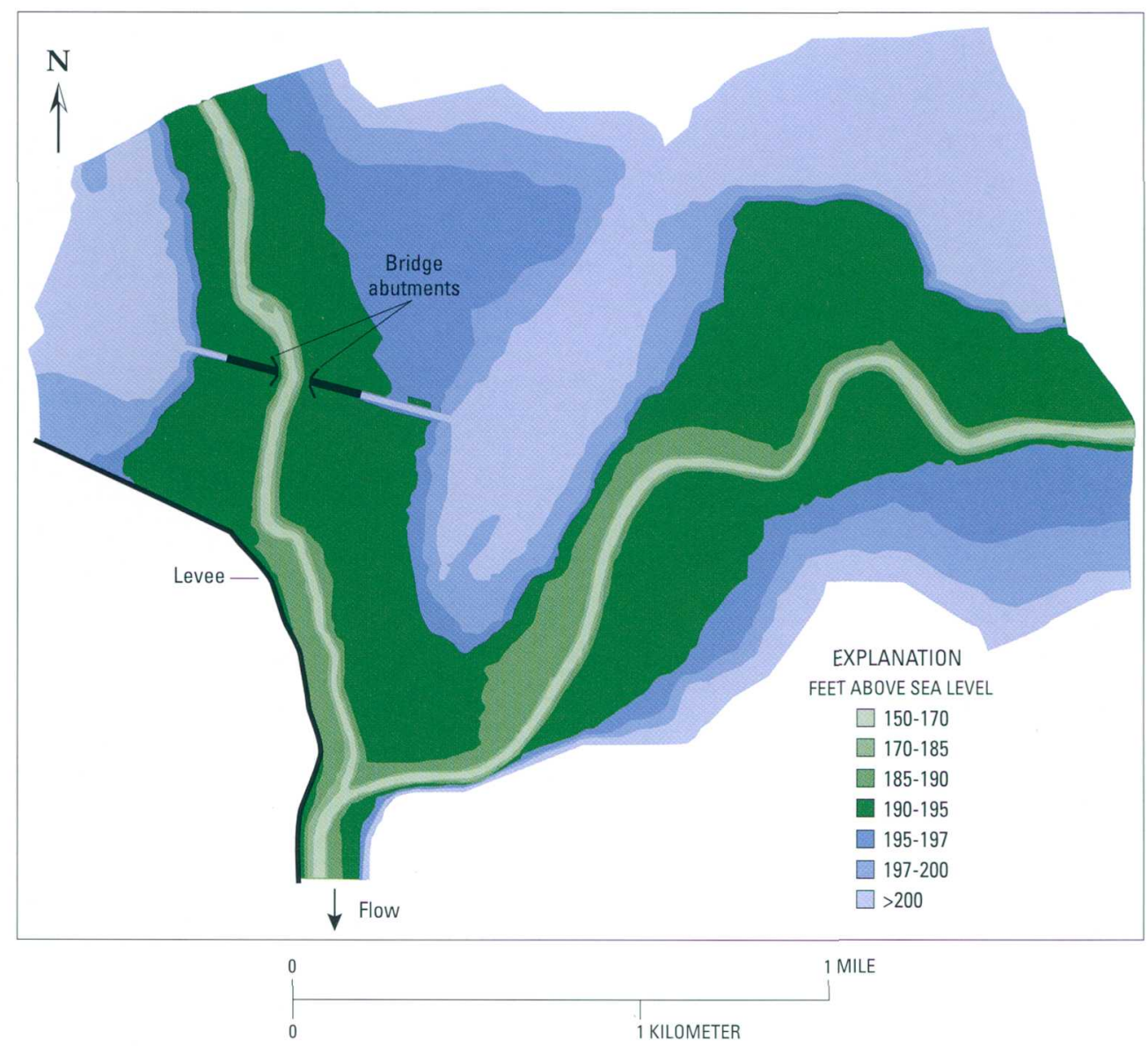

Figure 3. Land-surface elevations for Pea River and Whitewater Creek study reach. 


\section{Model Description}

The Finite Element Surface-Water Modeling System for Two-Dimensional Flow in the Horizontal Plane (FESWMS-2DH) (Froehlich, 1989) was selected as an appropriate model for simulating the two-dimensional flows within the study reach. The model uses the Galerkin finite-element method to solve three partial-differential equations representing conservation of mass and momentum (Lee and Froehlich, 1989). A depth-averaged velocity is computed at each computational point (node) in the model domain. The model area is divided into triangular sections (elements) of variable size, which are better for fitting the model to physical features. Input data requirements can be put into three major categories:

1. Geographical information. Land-surface elevations for each element, and dimensions and locations of each element (as defined by the computational grid).

2. Flow parameters. Resistance coefficients for each element, possibly as a variable function of depth or velocity; also kinematic eddy viscosity.

3. Boundary conditions. Flow conditions at the edges of the model are either water-surface elevations or discharge. Boundary conditions are required to execute the model.

The theory of the model is beyond the scope of this report; however, a detailed explanation of the theory is provided in the report by Lee and Froehlich (1989).

\section{Model Implementation}

Several steps are involved in the application of a twodimensional finite-element flow model. First, a finite-element grid representing the flow system must be constructed and tested for its integrity. Once a stable grid has been constructed, boundary conditions, such as water-surface elevation and(or) discharge, must be determined to execute the model. Finally, several model parameters and options must be considered before it can be determined which model will produce the best results for floodflow simulations.

\section{Computational Grid}

The use of a finite-element model requires that the study reach be divided into elements that form a grid. In a triangular grid, nodes are located at the corners and midsides of the elements and are assigned coordinates and elevations. A finite-element grid should be carefully designed so that mass is conserved within the system. The finite-element grid needs to be more refined (smaller elements) in areas where changes in velocity or bathymetry are substantial than in areas where changes are gradual. The software package FEMI (R.R. McDonald, U.S. Geological Survey, oral commun., 1999) was used to construct the computational grids to represent the flow system in this study. FEMI consists of an automated grid generator, GRIDGEN, that uses vertex triangulation methods in which vertices (nodes) are distributed through the model domain and then connected appropriately by a triangulation algorithm. The finiteelement grid used for modeling the existing conditions consists of 6,415 elements and 13,048 nodes (fig. 4),

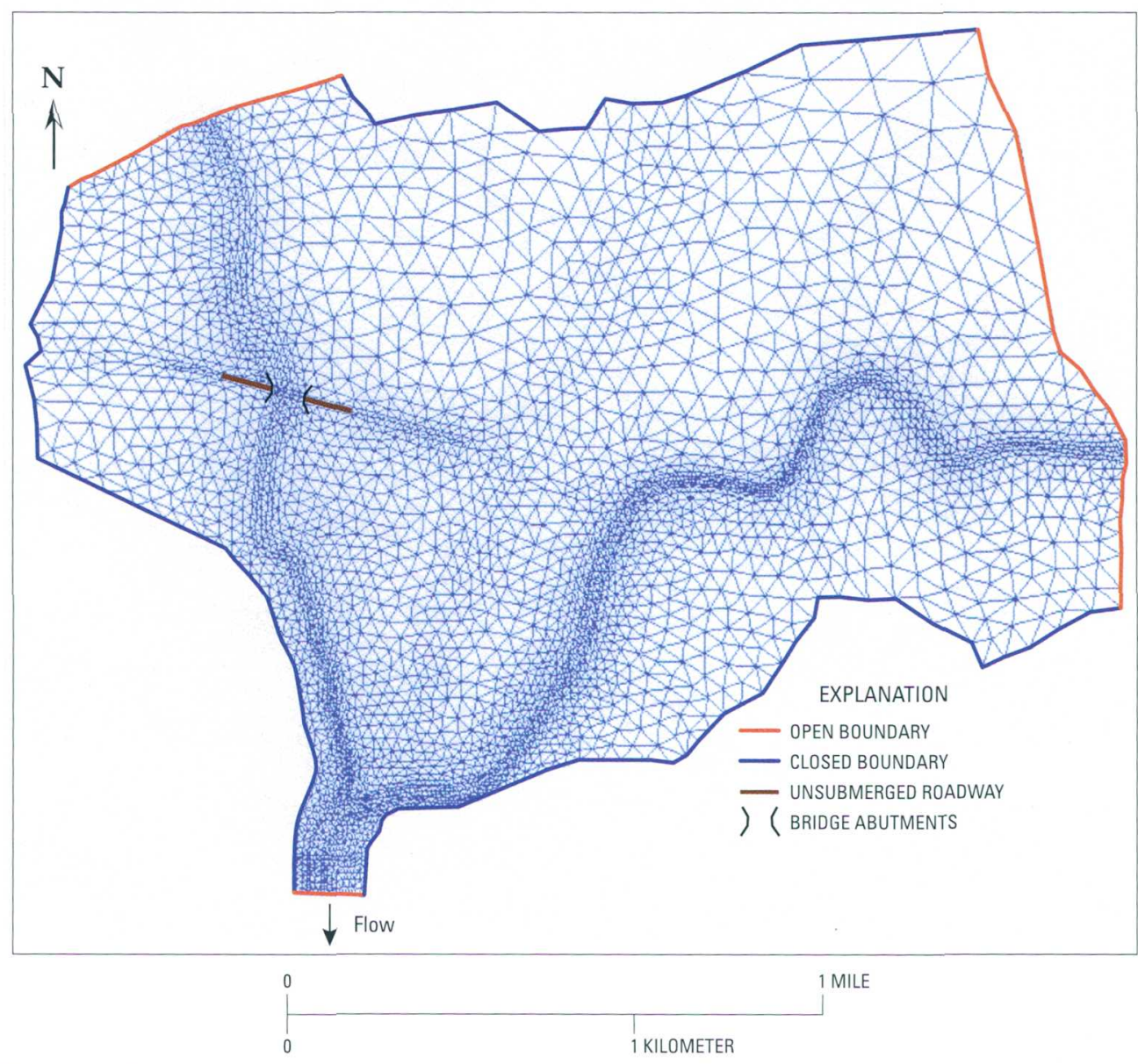

Figure 4. Finite-element grid used in flow simulations for existing conditions 
while the grid for the proposed conditions has 6,455 elements and 13,218 nodes (fig. 5). and the upstream end of the Whitewater Creek study reach. The open boundary conditions at the upstream

boundary are the discharges for the different flows being simulated. The open boundary conditions for the downstream end of the study reach are water-surface elevations estimated from either surveyed flood profiles or the rating curve developed for the gage. A downstream boundary condition of $201.9 \mathrm{ft}$ was estimated from flood profiles surveyed by the USGS and the USACE for the flood of March 17, 1990. The downstream boundary conditions estimated using the rating curve developed for the gage are $200.26 \mathrm{ft}$ and $202.95 \mathrm{ft}$ for the 50- and 100-year floods, respectively. The downstream boundary condition for the 100-year flood reflecting levee modifications $(203.67 \mathrm{ft})$ was estimated by extending the rating curve developed for the gage.

Figure 5. Finite-element grid used in flow simulations for proposed conditions

\section{Boundary Conditions}

Boundary conditions are established around the perimeter of a finite-element network and are identified as either closed or open. Closed boundaries represent obstructions, such as shorelines, embankments, and levees, that do not allow flow to pass through. The locations of the closed boundaries, representing the shorelines in this study, were estimated using watersurface profiles surveyed by the USGS and the USACE for the flood of March 17, 1990, and profiles determined from WSPRO [a one-dimensional step-backwater model used for computing water-surface profiles (Shearman, 1990)]. For the simulations in this study, all closed boundaries were set up for a tangential slip condition, which forces all flow adjacent to the closed boundaries to flow parallel to the boundaries.

Open boundaries allow flow to enter or leave the finite-element network. In this study, open boundaries are located at the upstream and downstream ends of Pea River

\section{Model Parameters}

Several modeling parameters and options were considered and varied throughout the modeling process to ensure that the best simulation of floodflows was achieved. Manning's roughness coefficient $(n)$ and base kinematic eddy viscosity (eq. 4-19, Froehlich, 1989) were the two primary model parameters varied throughout the modeling process. Manning's roughness coefficients for the March 1990 flood-plain conditions were selected based on topographic maps and aerial photographs (fig. 6). Manning's roughness coefficients for both the existing and proposed conditions were selected based on field investigations made during the summer of 2001 (fig. 7).

Default values for all other modeling parameters were used for floodflow simulations. These parameters included the following: water density, air density, dimensionless turbulence coefficient, relaxation factor, depth tolerance, and coefficients used to compute the 


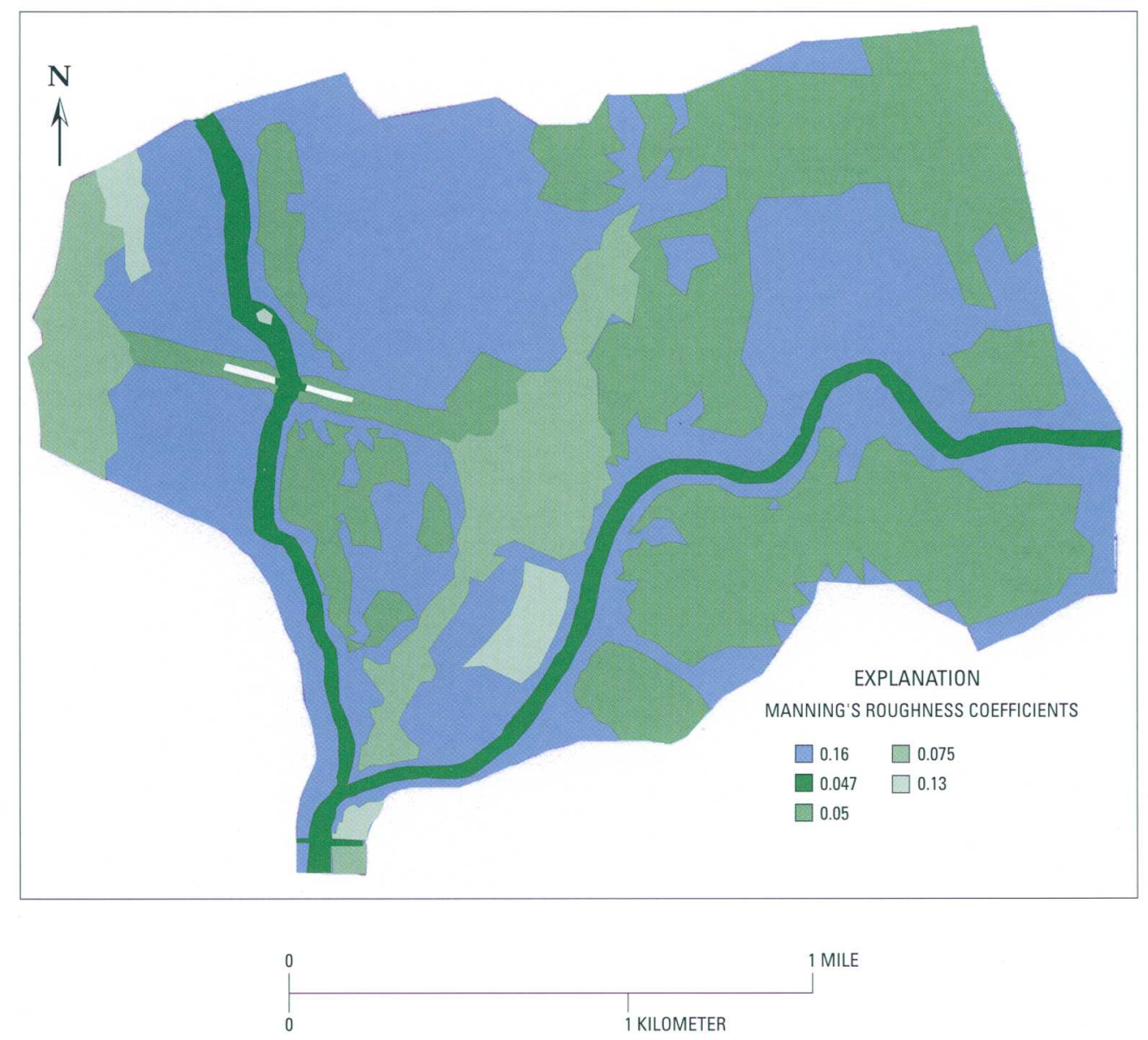

Figure 6. Manning's roughness coefficients used for simulation of March 1990 flood.

momentum correction coefficient. Additionally, a loworder numerical integration technique was performed for each simulation. Wind effects were ignored, and a constant density was assumed (assumed flow was well mixed vertically). Any unsteady effects of the floodflow were ignored. Some of the modeling options that were considered were (1) steady-state versus time-dependent solution, (2) elements "turned on" and "off" during a run versus elements left "on" (Froehlich, 1989), and (3) varying the number of iterations to be performed to reach a converged solution. 

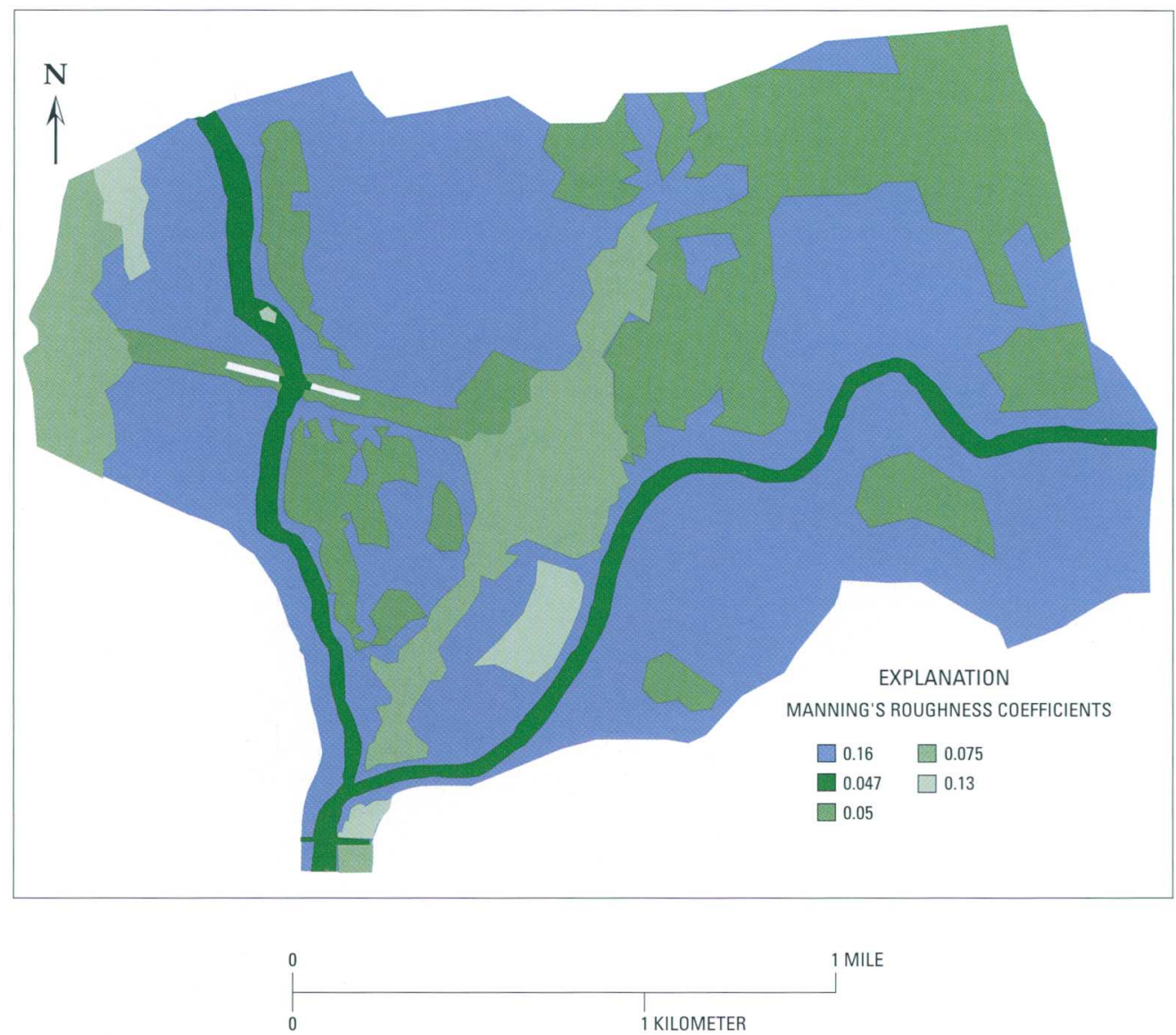

Figure 7. Manning's roughness coefficients used for simulations of existing and proposed conditions.

\section{Model Calibration and Validation}

Calibration is the process of adjusting model input parameters so that model results closely compare to actual measured data. Data from the flood of March 17, 1990, were used as the calibration data for this study. These data include the surveyed flood profile for the flood, a rating curve developed for the gaging station, and a stage hydrograph for the flood. The model input parameters adjusted during model simulation were Manning's roughness coefficients and base kinematic eddy viscosity. These parameters were adjusted until the computed water-surface elevations closely matched the measured data from the 1990 flood. The proper technique for validating a calibrated model is to simulate a separate hydraulic event for which the discharge and water-surface elevations are known independent of the original event. If no model parameters are adjusted to reach a solution comparable to the recorded data for the independent event, the model is commonly considered well calibrated for a limited range of discharges. Since there was no other recorded event with sufficient data for comparison, it was not possible to validate the calibrated model.

\section{Sensitivity Analy sis}

The sensitivity of model results to changes in model parameters was observed. Manning's roughness coefficients $(n)$ and base kinematic eddy viscosity were adjusted from the original values used in the initial convergence of the model. Changes in Manning's $n$ for elements in the overbank areas had minimal effects on the model results. Manning's $n$ for overbank elements was varied by 25 percent, resulting in less than $0.1 \mathrm{ft}$ change in computed water-surface elevations at the bridge openings and upstream end of the study reach. Likewise, changes in Manning's $n$ in the channel had little effect on computed water-surface elevations. Manning's $n$ was varied between 0.047 and 0.059 , resulting in an increase of about $0.1 \mathrm{ft}$ in computed water-surface elevations at the bridge openings and upstream end of the study reach. 
Changes in base kinematic eddy viscosity had somewhat significant effects on the solution. For each floodflow simulation, a beginning base kinematic eddy viscosity of $100 \mathrm{ft}^{2} / \mathrm{s}$ was used. Once a converged solution was reached for the targeted boundary conditions, the base kinematic eddy viscosity was lowered in a series of steps to a value of $10 \mathrm{ft}^{2} / \mathrm{s}$, which was used for the final simulation for each flooding scenario. For base eddy viscosities between 100 and $30 \mathrm{ft}^{2} / \mathrm{s}$, significant changes were observed in the solution (about $0.5 \mathrm{ft}$ ) at the upstream ends of the study reach. For base eddy viscosities between 30 and $10 \mathrm{ft}^{2} / \mathrm{s}$, however, no significant changes were observed in the solution (less than $0.15 \mathrm{ft}$ ) at the upstream boundaries.

\section{SIMULATION OF FLOODFLOWS}

Floodflows for the 50- and 100-year floods were simulated for both the existing and proposed conditions. The 50- and 100-year flood discharges were simulated because hydraulic structures are designed by the ALDOT to meet Federal, State, and local guidelines. These guidelines require the design of a hydraulic structure to adequately pass the 50-year flood such that a targeted design velocity is achieved in the bridge opening. For the 100-year flood, current guidelines require that backwater is not excessively increased. Additionally, these

guidelines require that theoretical scour be computed for the proposed hydraulic structures for the 100-year flood. Prior to the simulation of these floodflows, the flood of March 17, 1990, was simulated for existing conditions to calibrate the model to an actual recorded event. For each simulation, the difference between the sum of the total bridge, roadway, and flood-plain discharge and the total input discharge is due to small, local mass conservation errors (Lee and Froelich, 1989).

\section{Flood of March 17, 1990}

Floodflow was simulated depicting the Pea River and Whitewater Creek flood of March 17, 1990, in the study reach. This simulation was performed with the present land and highway configuration in place, including the present embankments and bridge opening for the State Highway 203 corridor. The estimated flood discharge for the 1990 flood at the gage was $58,000 \mathrm{ft}^{3} / \mathrm{s}$, which is between the 50 - and 100-year floods $\left(51,400 \mathrm{ft}^{3} / \mathrm{s}\right.$ and $63,500 \mathrm{ft}^{3} / \mathrm{s}$, respectively). During the March 1990 flood, the average depth in the Whitewater Creek channel in the vicinity of State Highway 203 was about $39 \mathrm{ft}$, whereas the average depth in the overbank areas was about $9 \mathrm{ft}$. For Pea River, the average depth in the channel in the vicinity of the proposed bypass was about $44 \mathrm{ft}$, and the average depth in the overbank areas was about $9 \mathrm{ft}$. The majority of State Highway 203 was overtopped.

Simulation of the March 1990 floodflow indicates that 34.5 percent $\left(20,000 \mathrm{ft}^{3} / \mathrm{s}\right)$ of the peak flow was conveyed by the State Highway 203 bridge over Whitewater Creek, 24.3 percent $\left(14,100 \mathrm{ft}^{3} / \mathrm{s}\right)$ overtopped the State Highway 203 embankment, and 41.2 percent $\left(23,900 \mathrm{ft}^{3} / \mathrm{s}\right)$ was conveyed by the Pea River flood plain east of State Highway 125. During this event, flow from Whitewater Creek $\left(4,890 \mathrm{ft}^{3} / \mathrm{s}\right)$ overtopped State Highway 125 and crossed into the Pea River flood plain north of State Highway 203, creating one common flood plain. The water-surface elevation predicted at the downstream side of the State Highway 203 bridge over Whitewater Creek was $204.72 \mathrm{ft}$. This compares closely to the high-water marks (average elevation $204.7 \mathrm{ft}$ ) recovered near the existing bridge. Computed watersurface elevations throughout the study reach compared closely (within $0.2 \mathrm{ft}$ ) to the surveyed flood profiles obtained after the flood. Finally, the maximum point velocity estimated at the Whitewater Creek bridge for the March 1990 flood was $3.7 \mathrm{ft} / \mathrm{s}$. A complete tabulation of the hydraulic data for the March 1990 flood for the existing bridge is presented in table 1. Computed watersurface elevations for the March 1990 flood for existing conditions are shown in figure 8 . Corresponding velocity contours are shown in figure 9 , and computed velocity contours and velocity vectors in the vicinity of State Highway 203 are shown in figures 10 and 11 , respectively. 
Table 1. Simulation of March 1990 flood

[Input discharge $=58,000$ cubic feet per second $\left(\mathrm{ft}^{3} / \mathrm{s}\right)$; FESWMS, finite-element surface-water modeling system; ft, feet; Vmax, maximum point velocity in feet per second $(\mathrm{ft} / \mathrm{s}) ;-$, no data]

\begin{tabular}{lccccc}
\hline \multicolumn{1}{c}{ Location } & $\begin{array}{c}\text { FESWMS } \\
\text { discharge } \\
\left(\mathbf{f t}^{3} / \mathbf{s}\right)\end{array}$ & $\begin{array}{c}\text { Percent of } \\
\text { total } \\
\text { FESWMS } \\
\text { flow }\end{array}$ & $\begin{array}{c}\text { FESWMS } \\
\text { downstream } \\
\text { stage } \\
(\mathbf{f t})\end{array}$ & $\begin{array}{c}\text { FESWMS } \\
\text { upstream } \\
\text { stage } \\
(\mathbf{f t})\end{array}$ & $\begin{array}{c}\text { FESWMS } \\
\text { Vmax } \\
(\mathrm{ft} / \mathbf{s})\end{array}$ \\
\hline Whitewater Creek existing bridge & 20,000 & 34.5 & 204.72 & 204.99 & 3.7 \\
State Highway 203 roadway & 14,100 & 24.3 & - & - & - \\
Pea River flood plain at approximate & $23,900^{\mathrm{a}}$ & 41.2 & - & - \\
$\quad$ location of proposed bypass & & & & & - \\
Total & $58,000^{\mathrm{b}}$ & & & \\
\hline
\end{tabular}

${ }^{\mathrm{a}}$ Flow conveyed by the Pea River flood plain east of State Highway 125.

${ }^{b}$ Difference between total bridge discharge and total input discharge is due to small, local mass conservation errors (Lee and Froelich, 1989).

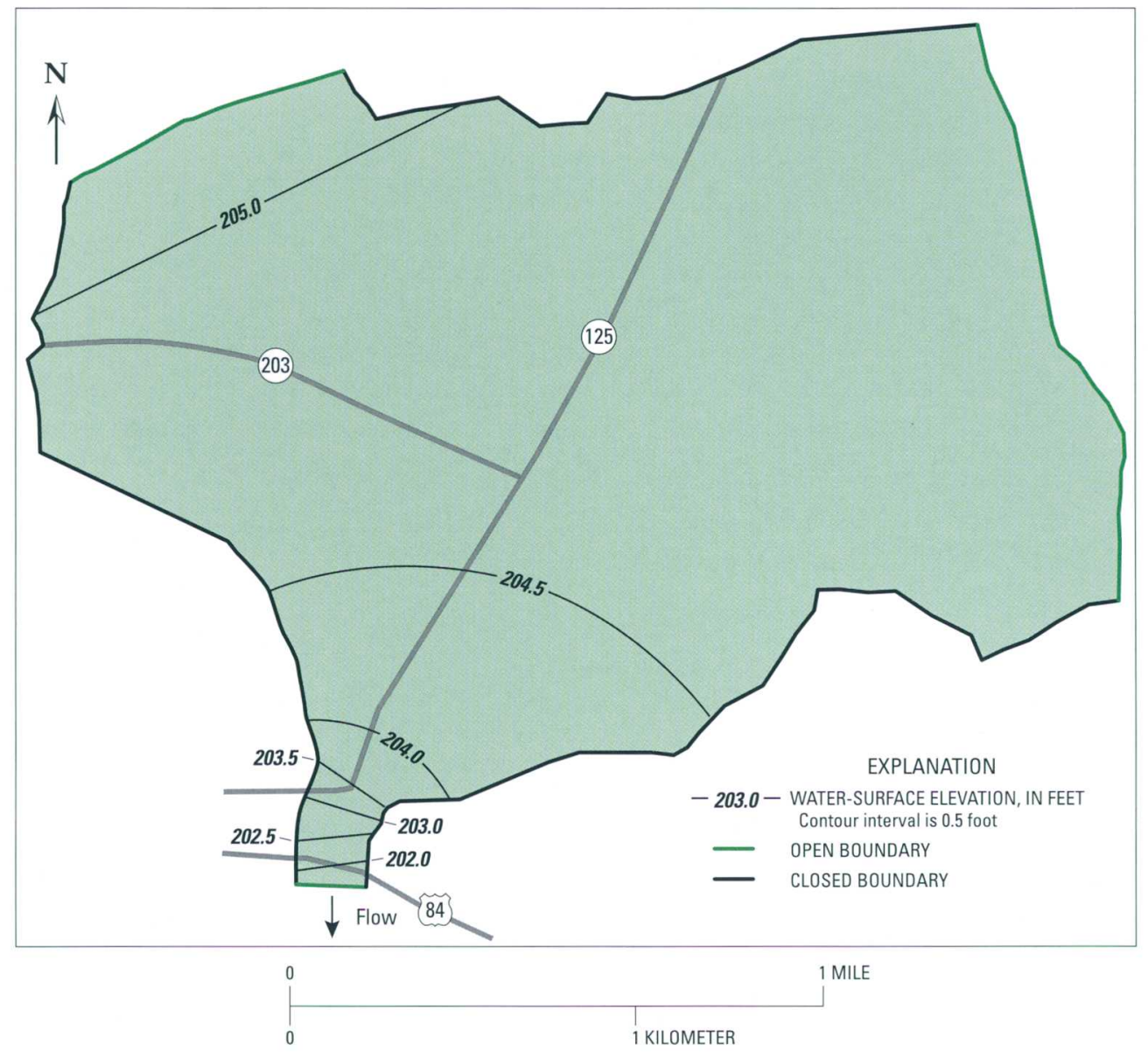

Figure 8. Computed water-surface elevations for March 1990 flood. 


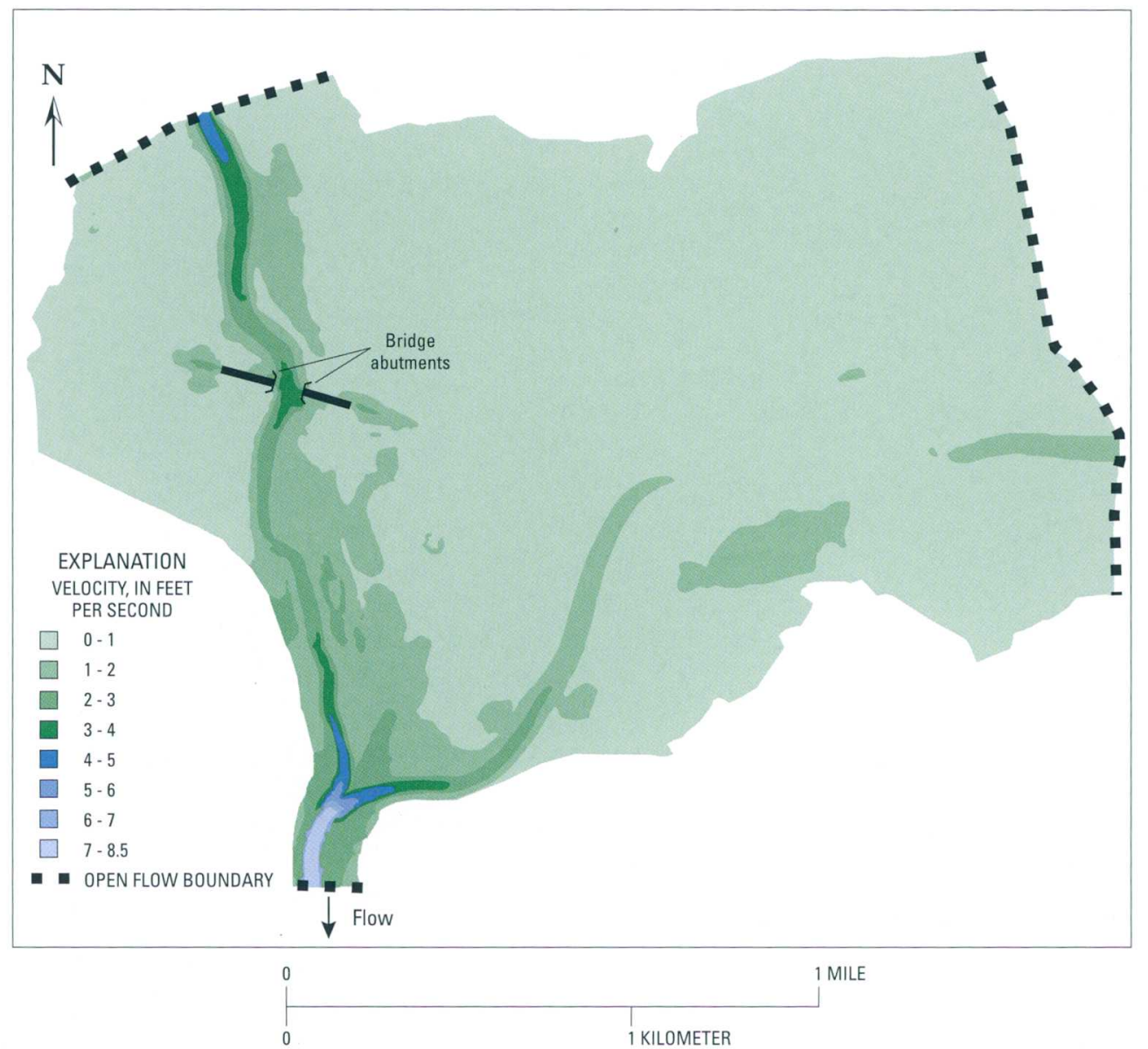

Figure 9. Computed velocity contours for March 1990 flood. 


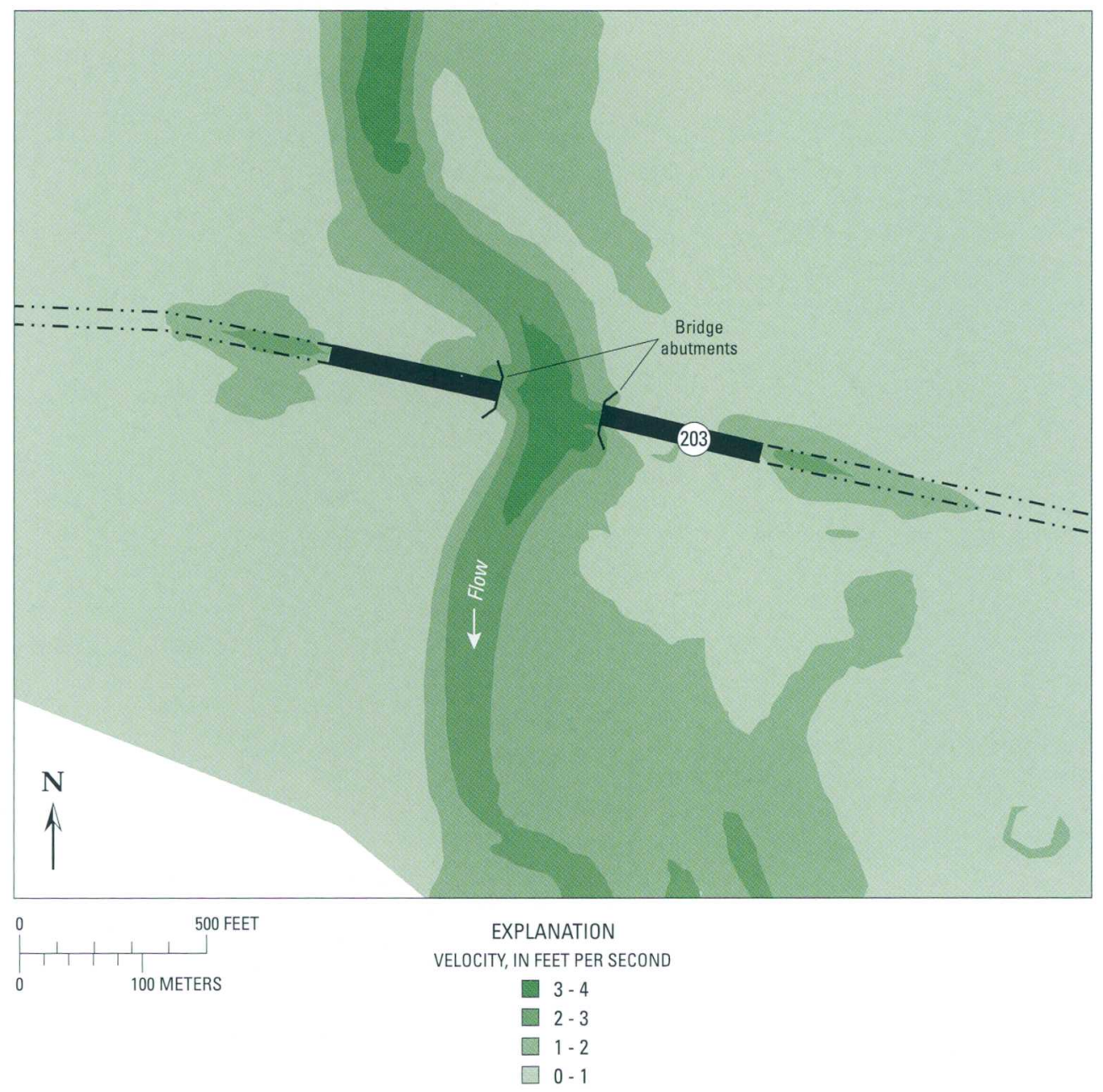

Figure 10. Computed velocity contours for March 1990 flood for existing State Highway 203 bridge crossing. 


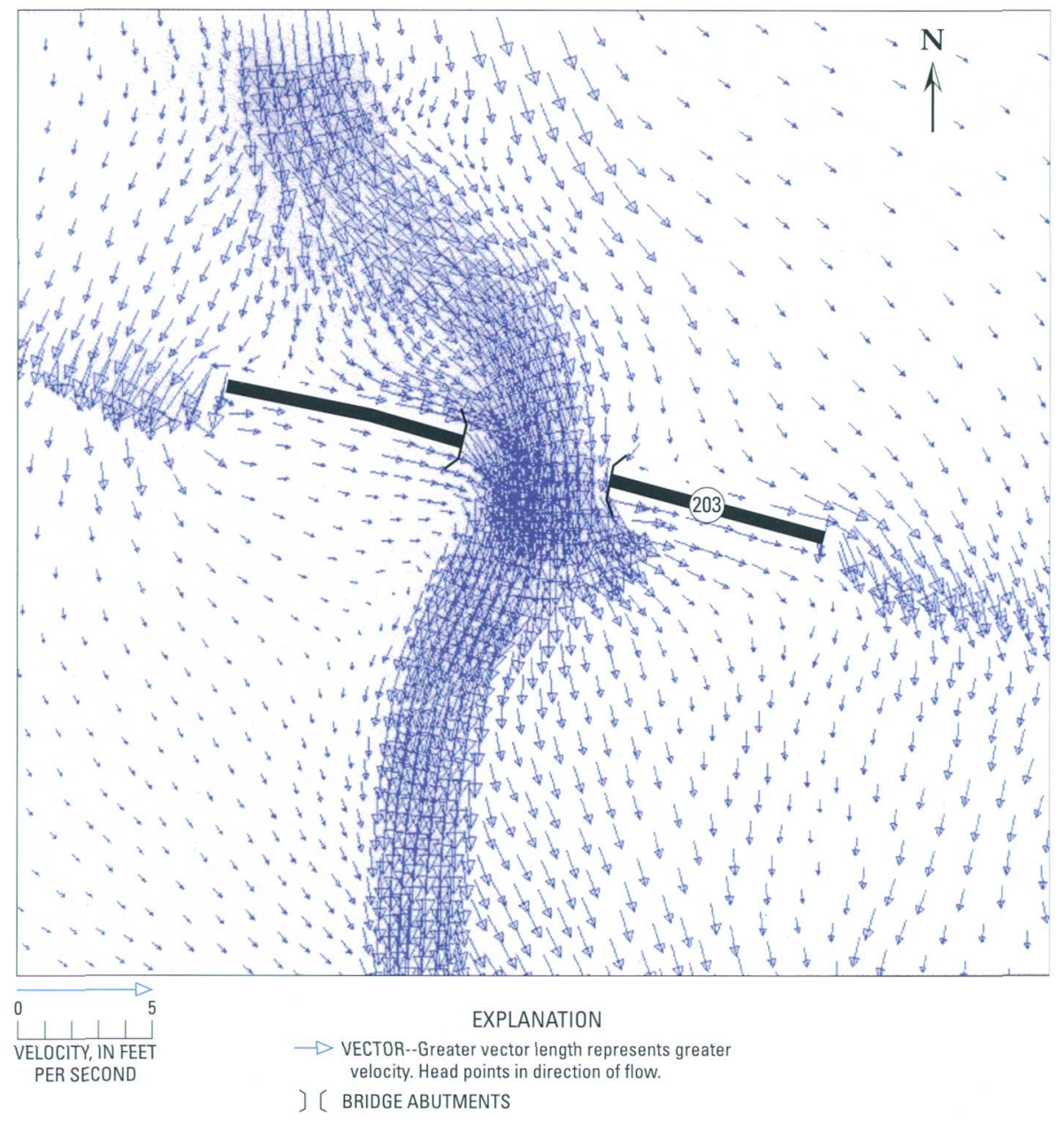

Figure 11. Computed velocity vectors for March 1990 flood for existing State Highway 203 bridge crossing.

\section{0-Year Flood}

Floodflows were simulated depicting the Pea River and Whitewater Creek 50-year flood for existing and proposed conditions. The estimated 50-year flood discharge at the gage is $51,400 \mathrm{ft}^{3} / \mathrm{s}$. This flood has a 2-percent chance of being equalled or exceeded in any given year. During the 50-year flood, the average depth in the Whitewater Creek channel in the vicinity of State Highway 203 was about $37 \mathrm{ft}$, whereas the average depth in the overbank areas was about $7 \mathrm{ft}$. For Pea River, the average depth in the channel in the vicinity of the proposed bypass was about $42 \mathrm{ft}$, whereas the average depth in the overbank areas was about $7 \mathrm{ft}$. For the existing conditions simulation, State Highway 203 was overtopped on both sides of the approach roadway.

\section{Existing Conditions}

Simulation of floodflows for the 50-year flood at the gage for existing flood-plain, bridge, highway, and levee conditions indicated that 30.9 percent $\left(15,900 \mathrm{ft}^{3} / \mathrm{s}\right)$ of the peak flow was conveyed by the State Highway 203 bridge over Whitewater Creek, 12.0 percent $\left(6,180 \mathrm{ft}^{3} / \mathrm{s}\right)$ overtopped the State Highway 203 embankment, and 57.0 percent $\left(29,300 \mathrm{ft}^{3} / \mathrm{s}\right)$ was conveyed by the Pea River flood plain east of State Highway 125. During this event, flow from Pea River $\left(2,380 \mathrm{ft}^{3} / \mathrm{s}\right)$ overtopped State Highway 125 and crossed over into the Whitewater Creek flood plain north of State Highway 203, creating one common flood plain. The water-surface elevation predicted at the downstream side of the State Highway 203 bridge over Whitewater Creek was $202.82 \mathrm{ft}$. Simulation of floodflows for the 50-year flood at the gage 
for existing flood-plain and levee conditions, with the State Highway 203 embankment and bridge removed, yielded a lower water-surface elevation (202.90 ft) upstream of this bridge compared to the existing conditions. Simulation of floodflows for the 50-year flood at the gage for existing flood-plain, bridge, and highway conditions with proposed modifications (increased crest elevation) to the levee yielded the same water-surface elevations as those for the existing conditions. This is because the 50-year flood did not overtop the existing levee and, therefore, would not overtop a taller one.

Finally, the maximum point velocity estimated at the Whitewater Creek bridge for the 50-year flood was $2.9 \mathrm{ft} / \mathrm{s}$. Computed water-surface elevations for the 50year flood for existing conditions are shown in figure 12 . Corresponding velocity contours are shown in figure 13, and computed velocity contours in the vicinity of State Highway 203 are shown in figure 14.

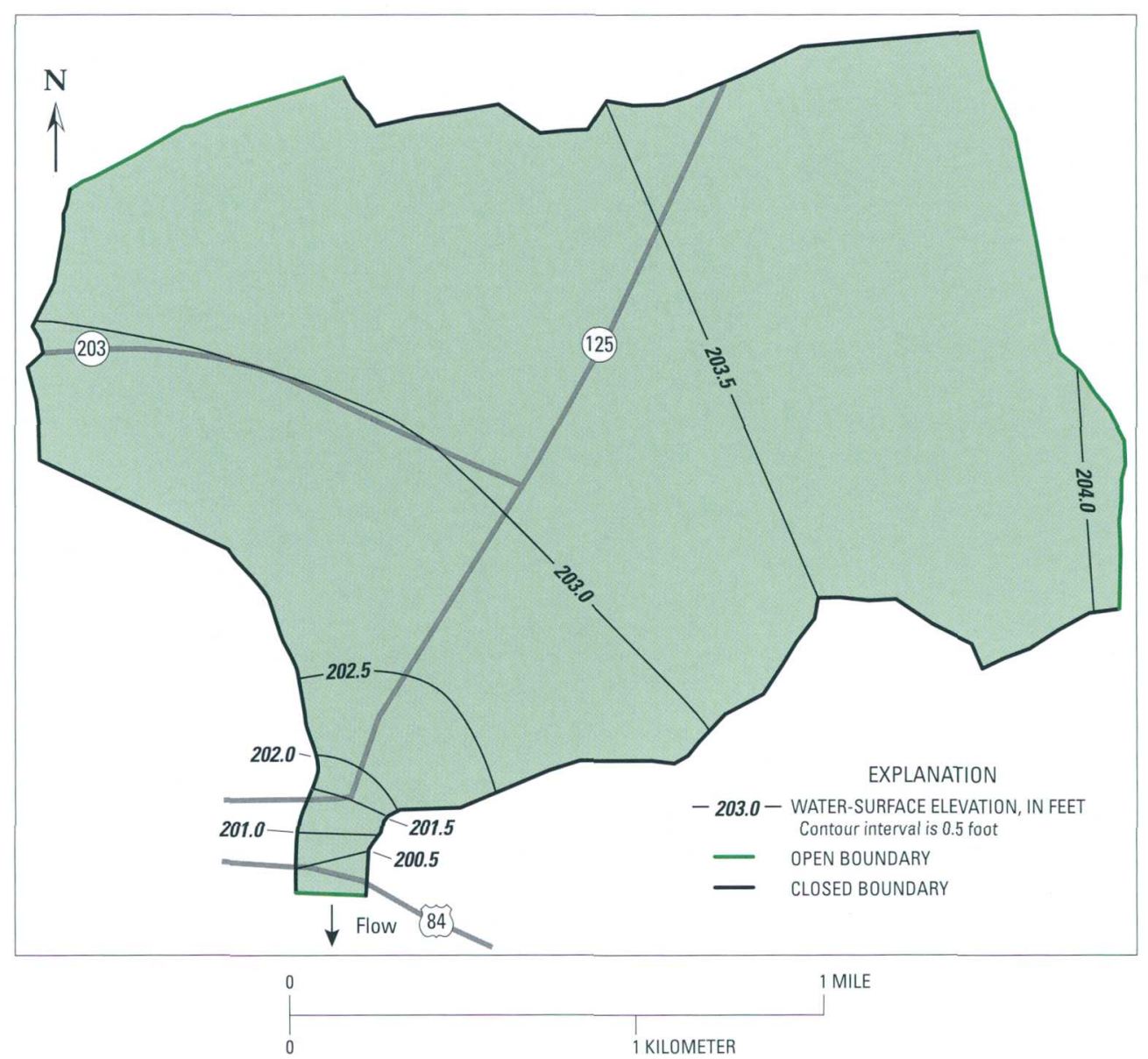

Figure 12. Computed water-surface elevations for 50-year flood for existing conditions. 


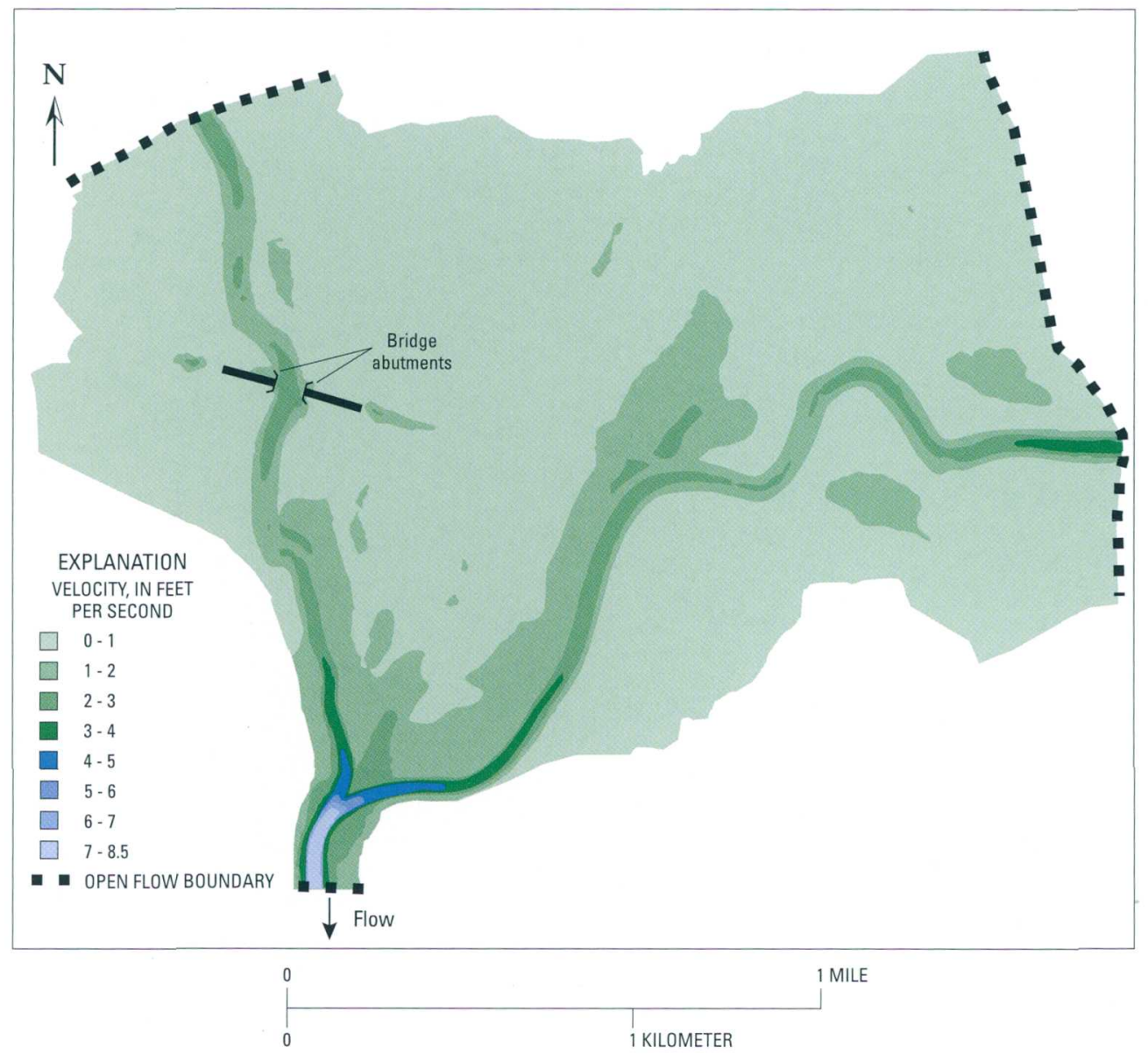

Figure 13. Computed velocity contours for 50-year flood for existing conditions. 


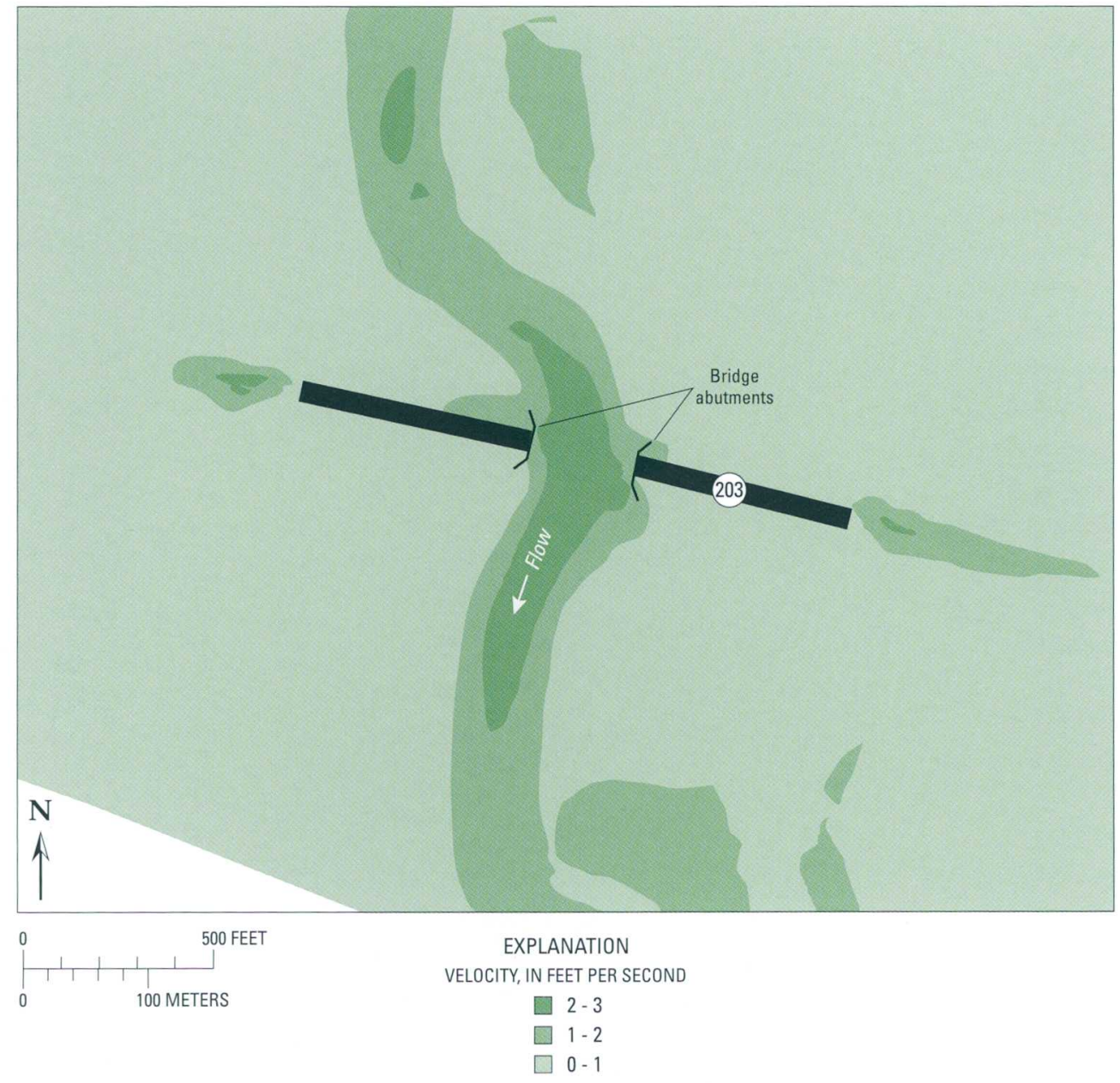

Figure 14. Computed velocity contours for 50-year flood for existing State Highway 203 bridge crossing.

\section{Proposed Conditions}

Simulation of floodflows for the 50-year flood at the gage for the proposed conditions indicated that 43.0 percent $\left(21,600 \mathrm{ft}^{3} / \mathrm{s}\right)$ of the peak flow was conveyed by the proposed bridge over Whitewater Creek,

51.8 percent $\left(26,000 \mathrm{ft}^{3} / \mathrm{s}\right)$ by the proposed main channel bridge over Pea River, and 5.2 percent $\left(2,590 \mathrm{ft}^{3} / \mathrm{s}\right)$ by the proposed relief bridge for Pea River. During this event, flow from Pea River $\left(1,220 \mathrm{ft}^{3} / \mathrm{s}\right)$ overtopped State Highway 125 and crossed over into the Whitewater Creek flood plain north of the proposed bypass. The watersurface elevation predicted at the downstream side of the proposed bridge over Whitewater Creek was $202.77 \mathrm{ft}$, whereas the water-surface elevation predicted at the downstream side of the proposed main channel bridge over Pea River was 203.06 ft. No overtopping of the proposed bypass occurred.

The maximum point velocities estimated for the proposed bypass bridges for the 50-year flood were $3.2 \mathrm{ft} / \mathrm{s}$ at the proposed Whitewater Creek bridge, $3.6 \mathrm{ft} / \mathrm{s}$ at the proposed main channel bridge over Pea River, and $2.4 \mathrm{ft} / \mathrm{s}$ at the proposed Pea River relief bridge. For the bridges mentioned above, average downstream and approach water-surface elevations were estimated by taking the average of the water-surface elevations at a group of nodes on a line at the location of interest. Approach elevations were selected from nodes about one 
bridge length upstream from the bridge. The average water-surface elevation about one bridge length upstream from the proposed Whitewater Creek bridge was about $0.04 \mathrm{ft}$ higher than that computed for the existing conditions.

For the proposed Pea River bridges, the approach elevation about one bridge length upstream from each bridge was about $0.01 \mathrm{ft}$ higher than that computed for the existing conditions. A complete tabulation of the hydraulic data for the 50-year flood for the bridges mentioned above is presented in tables 2 and 3. Computed water-surface elevations for the 50-year flood for the proposed conditions are shown in figure 15 .

Corresponding velocity contours are shown in figure 16. Computed velocity contours in the vicinity of the proposed Whitewater Creek bridge are shown in figure 17. Computed velocity contours for the proposed Pea River bridges are shown in figure 18. Velocity vector plots for the Whitewater Creek and Pea River bridges are shown in figures 19 and 20 , respectively.

Table 2. Simulation of 50 -year flood for existing conditions

[Input discharge $=51,400$ cubic feet per second $\left(\mathrm{ft}^{3} / \mathrm{s}\right)$; FESWMS, finite-element surface-water modeling system; ft, feet; $V \max$, maximum point velocity in feet per second $(\mathrm{ft} / \mathrm{s}) ;$, no data]

\begin{tabular}{lccccc}
\hline \multicolumn{1}{c}{ Location } & $\begin{array}{c}\text { FESWMS } \\
\text { discharge } \\
\left(\mathbf{f t}^{\mathbf{3}} \mathbf{s}\right)\end{array}$ & $\begin{array}{c}\text { Percent of } \\
\text { total } \\
\text { FESWMS } \\
\text { flow }\end{array}$ & $\begin{array}{c}\text { FESWMS } \\
\text { downstream } \\
\text { stage } \\
\text { (ft) }\end{array}$ & $\begin{array}{c}\text { FESWMS } \\
\text { upstream } \\
\text { stage } \\
(\mathbf{f t})\end{array}$ & $\begin{array}{c}\text { FESWMS } \\
\text { Vmax } \\
\text { (ft/s) }\end{array}$ \\
\hline Whitewater Creek bridge & 15,900 & 30.9 & 202.82 & 203.02 & 2.9 \\
State Highway 203 roadway & 6,180 & 12.0 & - & - & - \\
$\begin{array}{l}\text { Pea River flood plain at approximate } \\
\quad \text { location of bypass }\end{array}$ & $29,300^{\mathrm{a}}$ & 57.0 & 203.20 & 203.44 & - \\
Total & $51,380^{\mathrm{b}}$ & & & & \\
\hline
\end{tabular}

aFlow conveyed by the Pea River flood plain east of State Highway 125.

${ }^{b}$ Difference between total bridge discharge and total input discharge is due to small, local mass conservation errors (Lee and Froelich, 1989).

Table 3. Simulation of 50 -year flood for proposed conditions

[Input discharge $=51,400$ cubic feet per second $\left(\mathrm{ft}^{3} / \mathrm{s}\right)$; FESWMS, finite-element surface-water modeling system; $\mathrm{ft}$, feet; $\mathrm{Vmax}$, maximum point velocity in feet per second $(\mathrm{ft} / \mathrm{s}) ;$ - no data]

\begin{tabular}{lccccc}
\hline \multicolumn{1}{c}{ Location } & $\begin{array}{c}\text { FESWMS } \\
\text { discharge } \\
\left(\mathbf{f t}^{\mathbf{3}} \mathbf{/} \mathbf{s}\right)\end{array}$ & $\begin{array}{c}\text { Percent of } \\
\text { total } \\
\text { FESWMS } \\
\text { flow }\end{array}$ & $\begin{array}{c}\text { FESWMS } \\
\text { downstream } \\
\text { stage } \\
(\mathbf{f t})\end{array}$ & $\begin{array}{c}\text { FESWMS } \\
\text { upstream } \\
\text { stage } \\
(\mathbf{f t})\end{array}$ & $\begin{array}{c}\text { FESWMS } \\
\text { Vmax } \\
(\mathbf{f t} / \mathbf{s})\end{array}$ \\
\hline Whitewater Creek bridge & 21,600 & 43.0 & 202.77 & 203.06 & 3.2 \\
Pea River main channel bridge & 26,000 & 51.8 & 203.06 & 203.44 & 3.6 \\
Pea River relief bridge & 2,590 & 5.2 & 203.08 & 203.46 & 2.4 \\
Total & $50,190^{\mathbf{a}}$ & & & & \\
\hline
\end{tabular}

a Difference between total bridge discharge and total input discharge is due to small, local mass conservation errors (Lee and Froelich, 1989). 


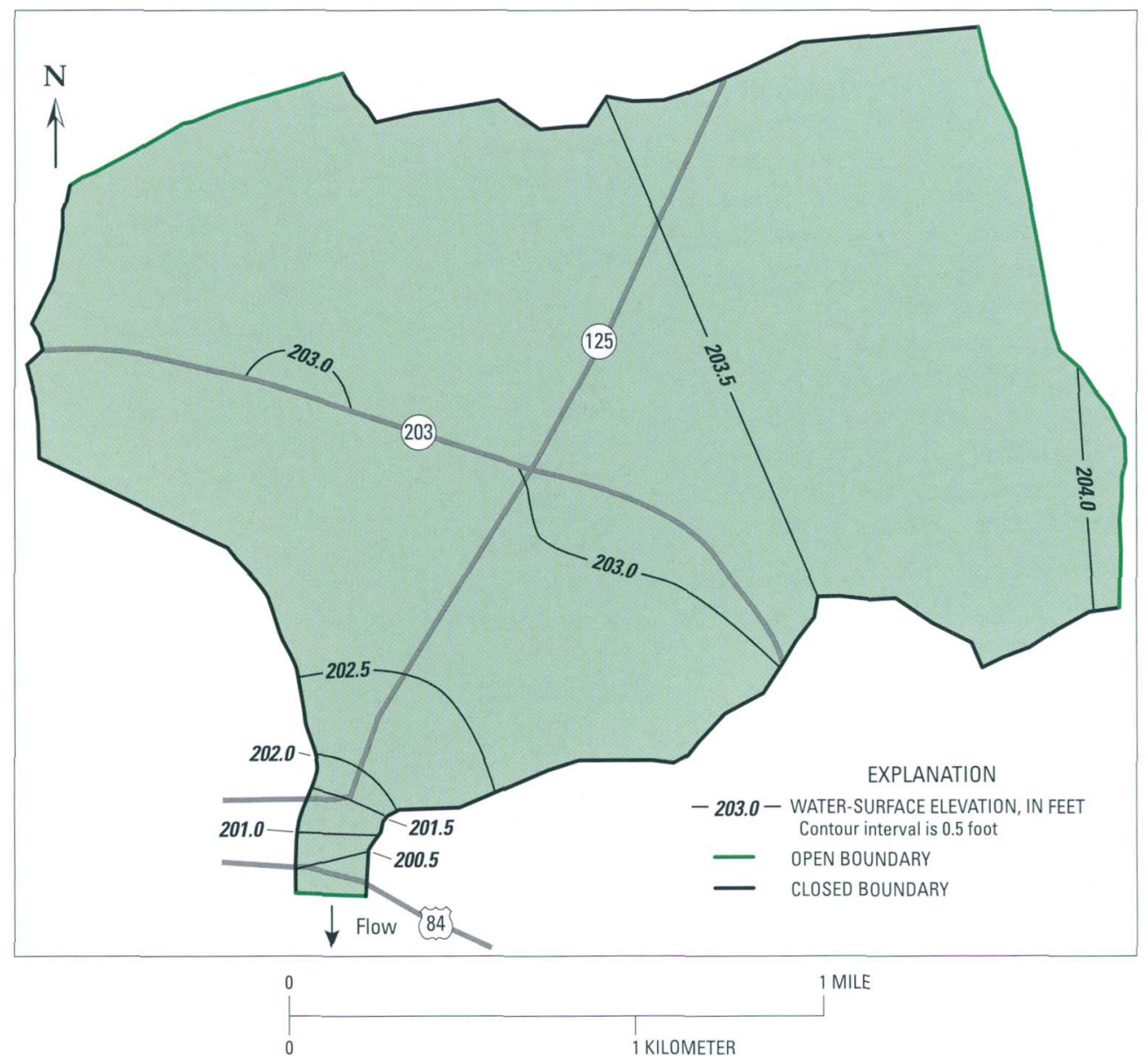

Figure 15. Computed water-surface elevations for 50-year flood for proposed conditions. 


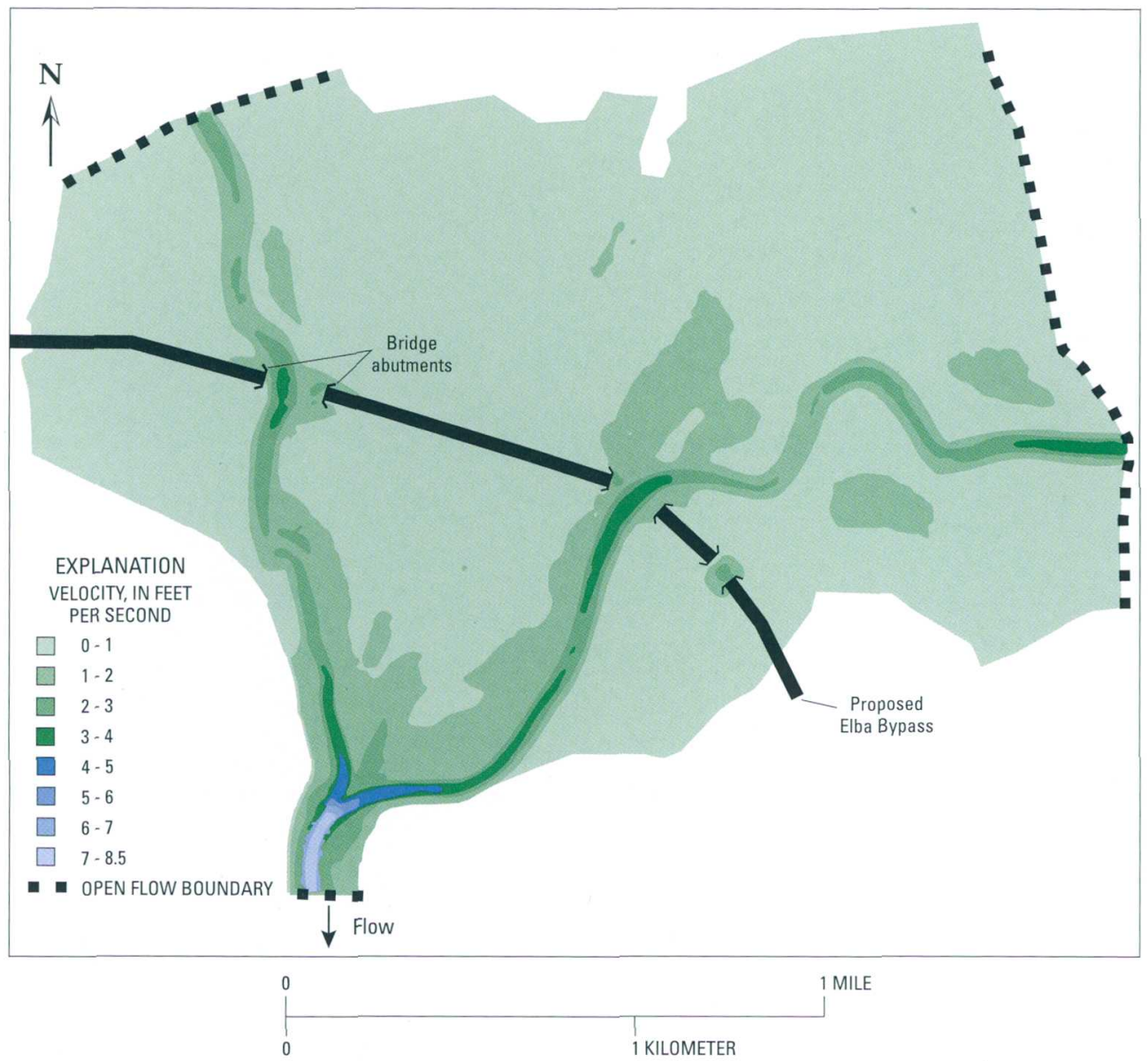

Figure 16. Computed velocity contours for 50 -year flood for proposed conditions. 


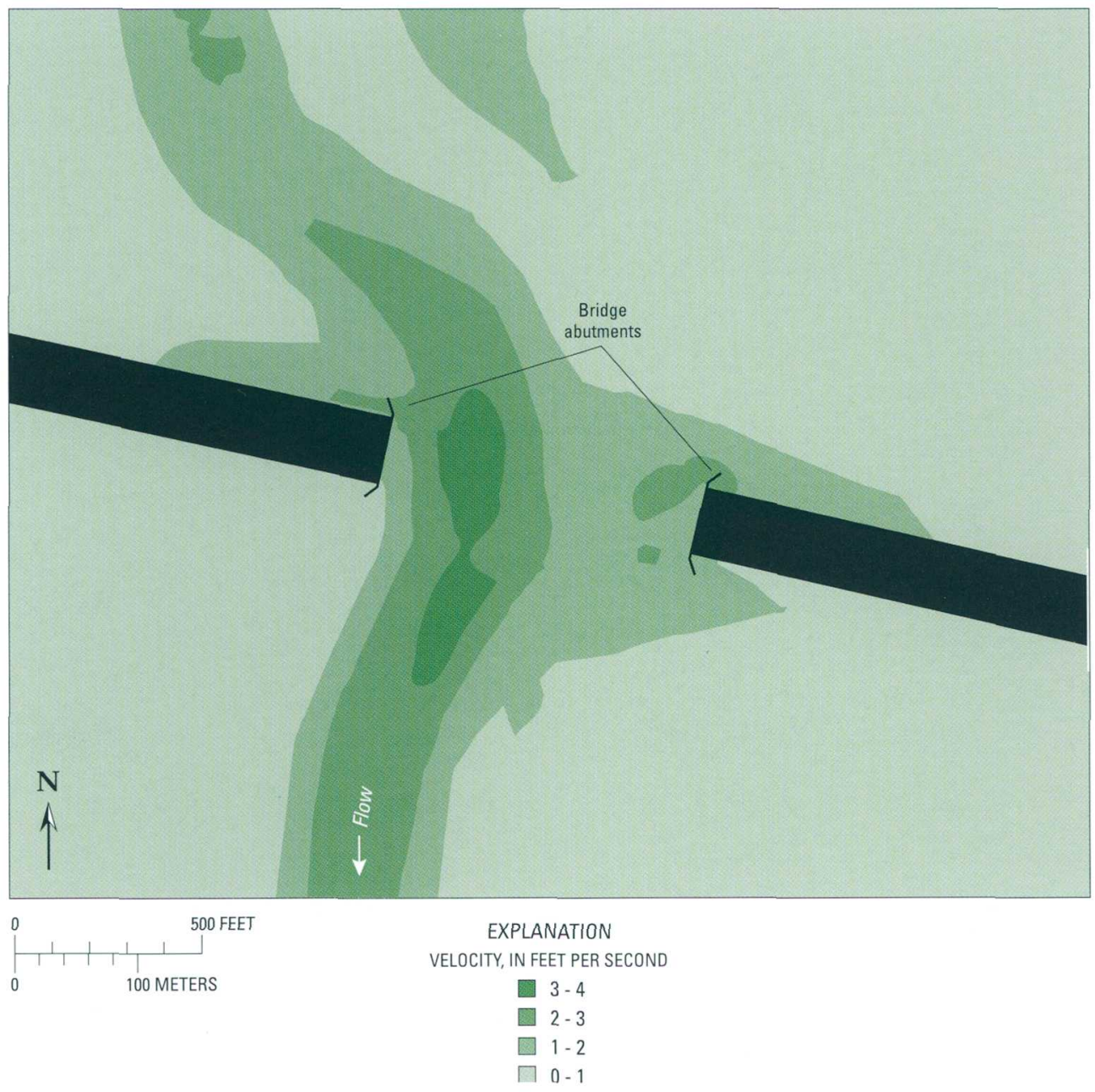

Figure 17. Computed velocity contours for 50-year flood for proposed bridge crossing of Whitewater Creek. 


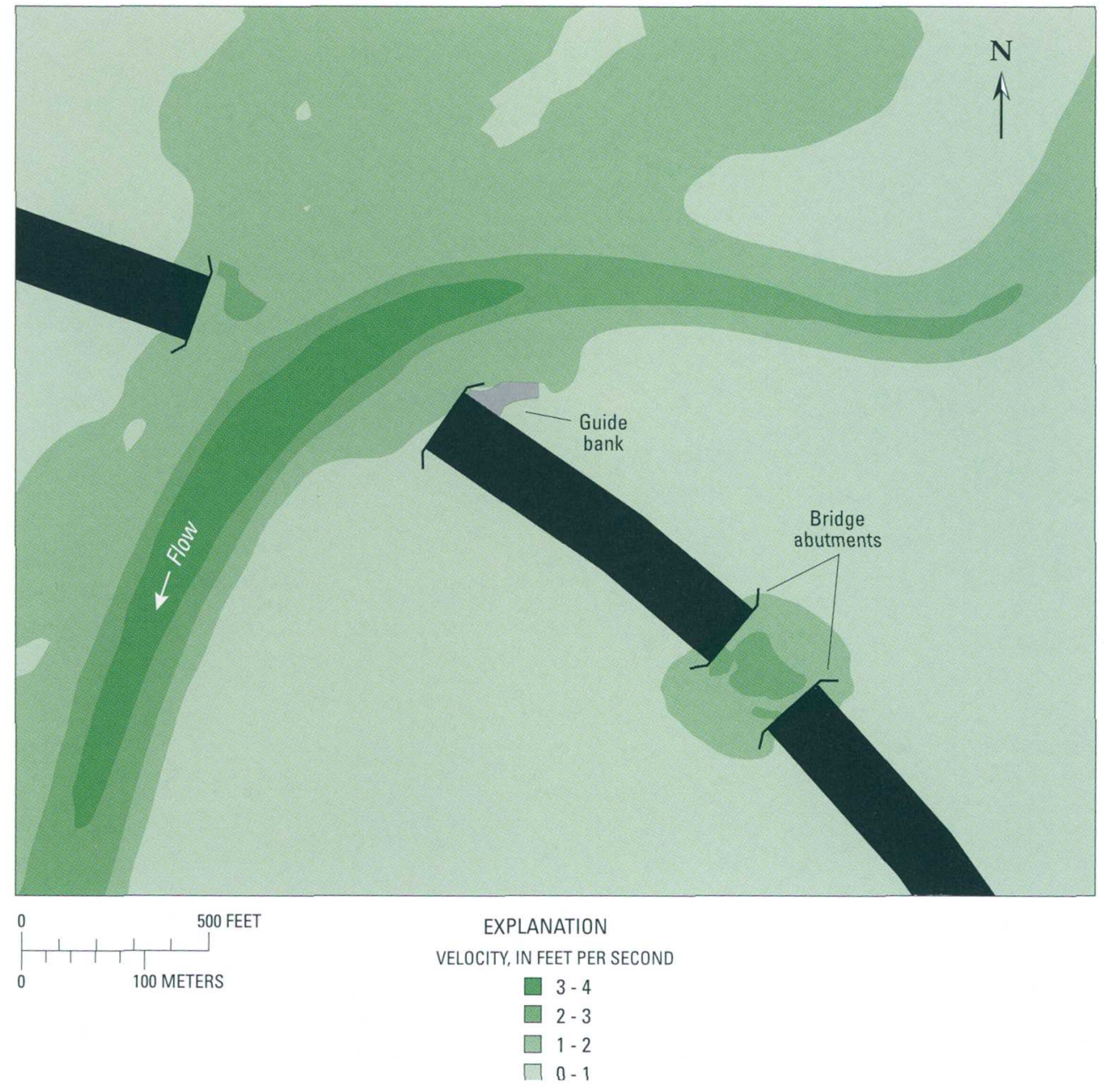

Figure 18. Computed velocity contours for 50-year flood for proposed bridge crossing of Pea River. 


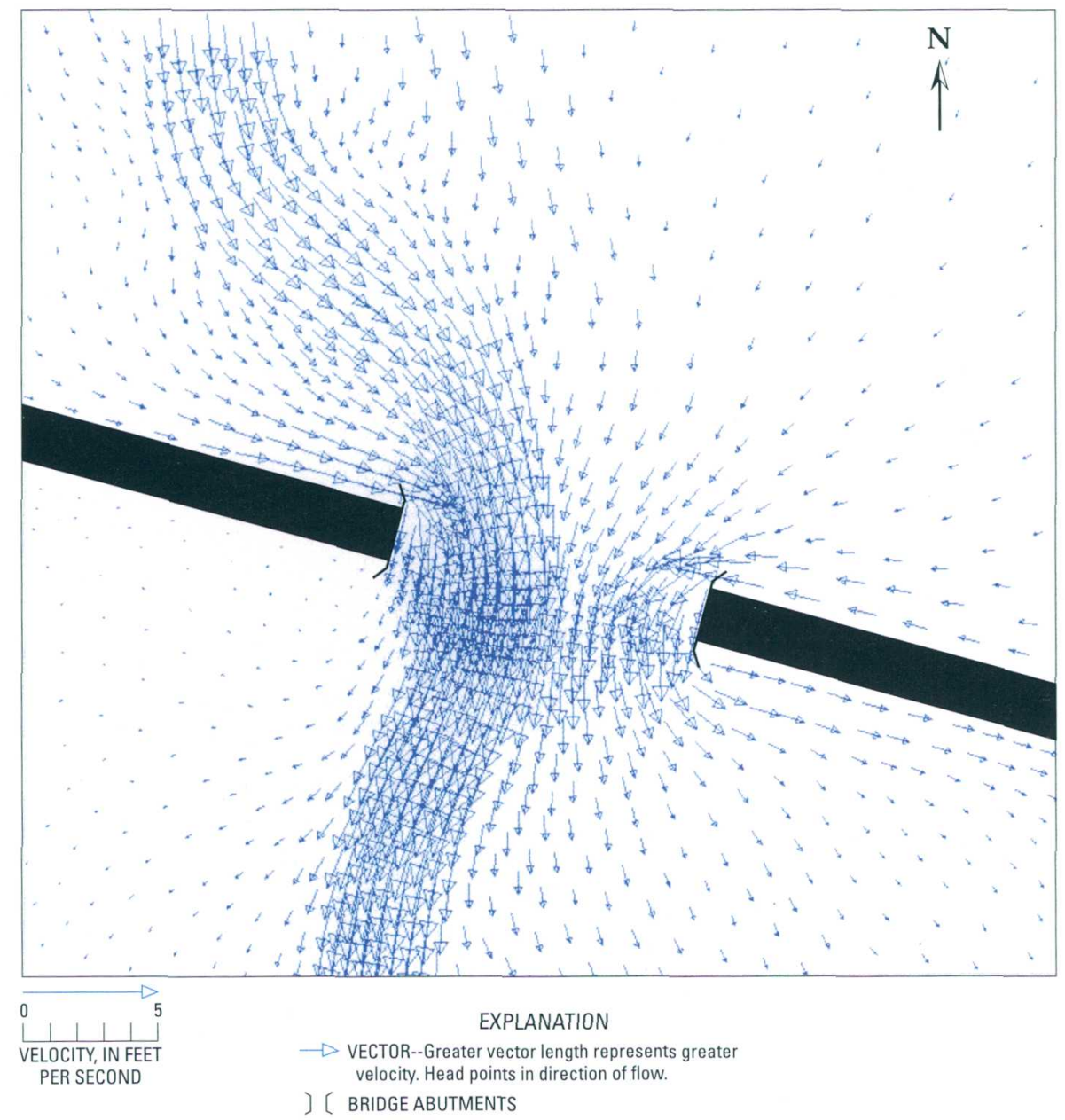

Figure 19. Computed velocity vectors for 50-year flood for proposed bridge crossing of Whitewater Creek. 


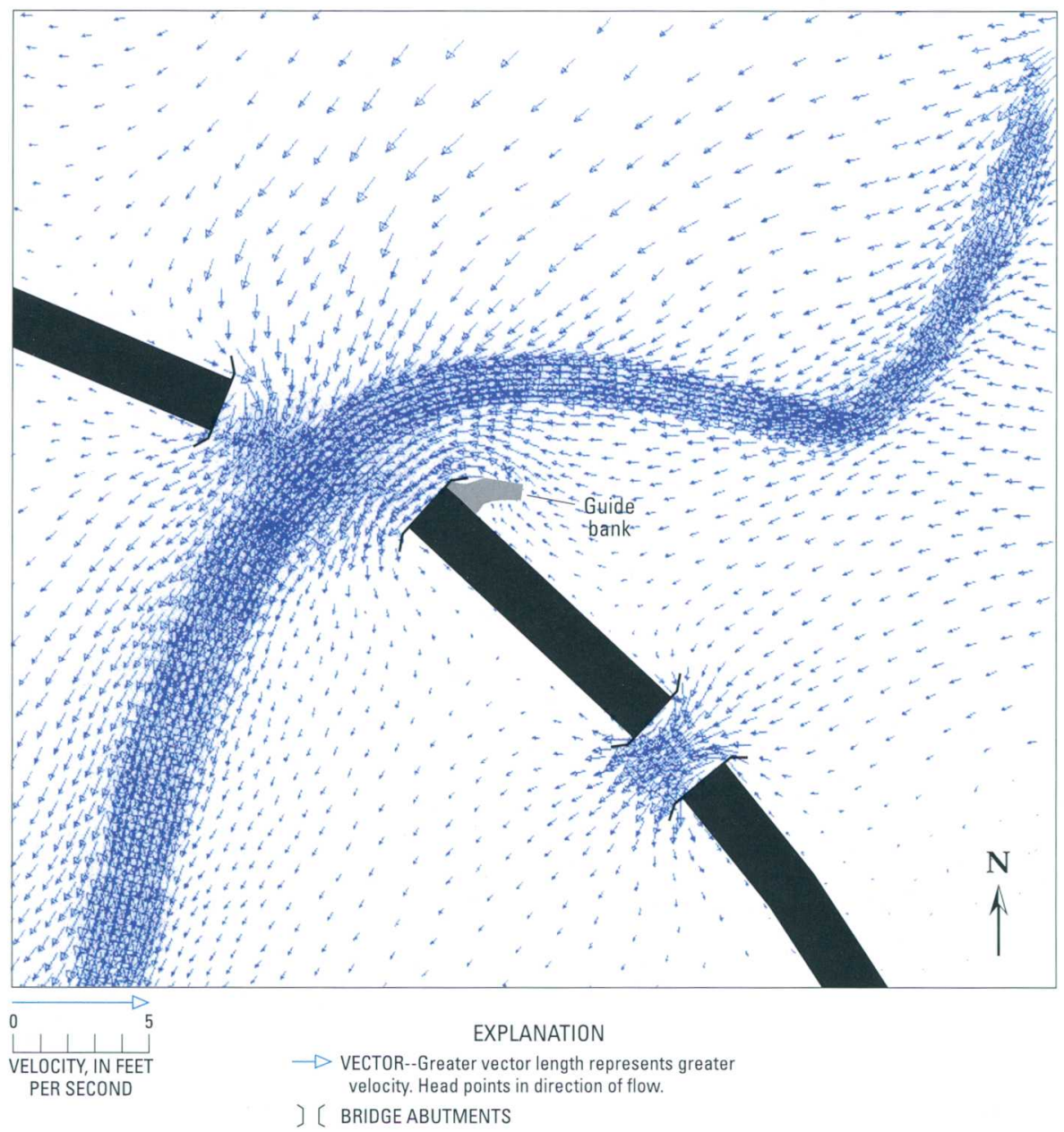

Figure 20. Computed velocity vectors for 50-year flood for proposed bridge crossing of Pea River.

\section{0-Year Flood}

Floodflows were simulated depicting the Pea River and Whitewater Creek 100-year flood for existing and proposed conditions. The estimated 100-year flood discharge at the gage is $63,500 \mathrm{ft}^{3} / \mathrm{s}$. This flood has a 1-percent chance of being equalled or exceeded in any given year. During the 100-year flood, the average depth in the Whitewater Creek channel in the vicinity of State Highway 203 was about $40 \mathrm{ft}$, whereas the average depth in the overbank areas was about $10 \mathrm{ft}$. For Pea River, the average depth in the channel in the vicinity of the proposed bypass was about $45 \mathrm{ft}$, whereas the average depth in the overbank areas was about $10 \mathrm{ft}$. For the existing conditions simulation, the majority of State Highway 203 was overtopped.

\section{Existing Conditions}

Simulation of floodflows for the 100-year flood at the gage for existing flood-plain, bridge, highway, and levee conditions indicated that 24.6 percent $\left(15,600 \mathrm{ft}^{3} / \mathrm{s}\right)$ of the peak flow was conveyed by the State Highway 203 bridge over Whitewater Creek, 24.1 percent $\left(15,300 \mathrm{ft}^{3} / \mathrm{s}\right)$ overtopped the State Highway 203 embankment, and 51.3 percent $\left(32,600 \mathrm{ft}^{3} / \mathrm{s}\right)$ was conveyed by the Pea River flood plain east of State Highway 125. During this event, flow from Pea River $\left(6,710 \mathrm{ft}^{3} / \mathrm{s}\right)$ overtopped State Highway 125 and crossed over into the Whitewater Creek flood plain north of State Highway 203, creating one common flood plain. The existing levee adjacent to Whitewater Creek was overtopped by a flow of $3,200 \mathrm{ft}^{3} / \mathrm{s}$ during the 100-year flood, whereas $60,700 \mathrm{ft}^{3} / \mathrm{s}$ flowed past the gage. The water-surface 
elevation predicted at the downstream side of the State Highway 203 bridge over Whitewater Creek was $205.60 \mathrm{ft}$. Simulation of floodflows for the 100-year flood at the gage for existing flood-plain and levee conditions, with the State Highway 203 embankment and bridge removed, yielded a lower water-surface elevation $(0.07 \mathrm{ft})$ upstream of this bridge than that for the existing conditions. Simulation of floodflows for a 100-year event at the gage for existing flood-plain, bridge, and highway conditions with proposed modifications (increased crest elevation) to the levee yielded a water-surface elevation about $0.7 \mathrm{ft}$ higher in the vicinity of State Highway 203 . U.S. Highway 84 was overtopped during this flood.

Finally, the maximum point velocity estimated at the Whitewater Creek bridge for the 100-year flood was $2.8 \mathrm{ft} / \mathrm{s}$. Computed water-surface elevations for the 100 year flood for the existing conditions are shown in figure 21 . Corresponding velocity contours are shown in figure 22, and computed velocity contours in the vicinity of State Highway 203 are shown in figure 23.

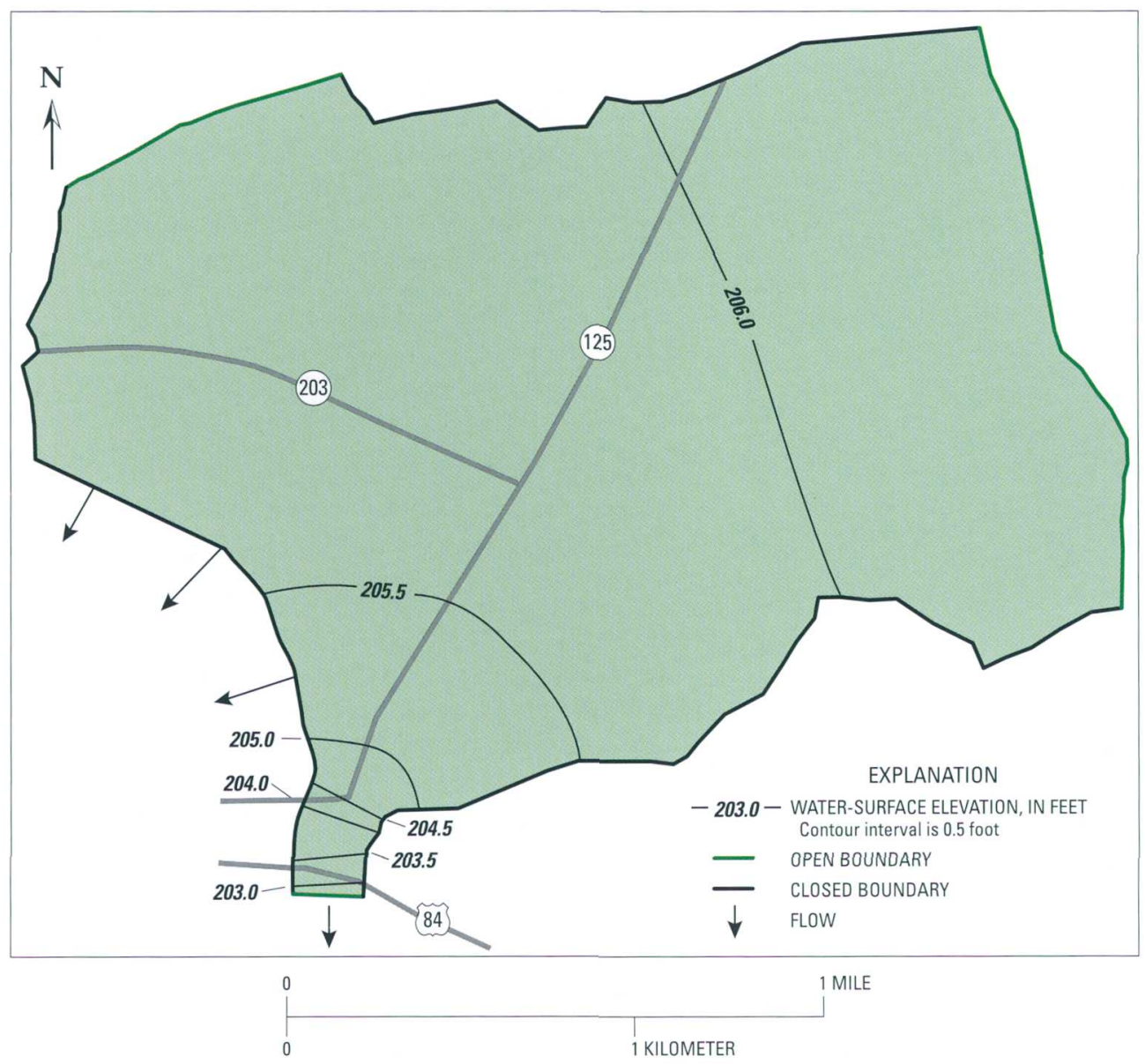

Figure 21. Computed water-surface elevations for 100-year flood for existing conditions. 


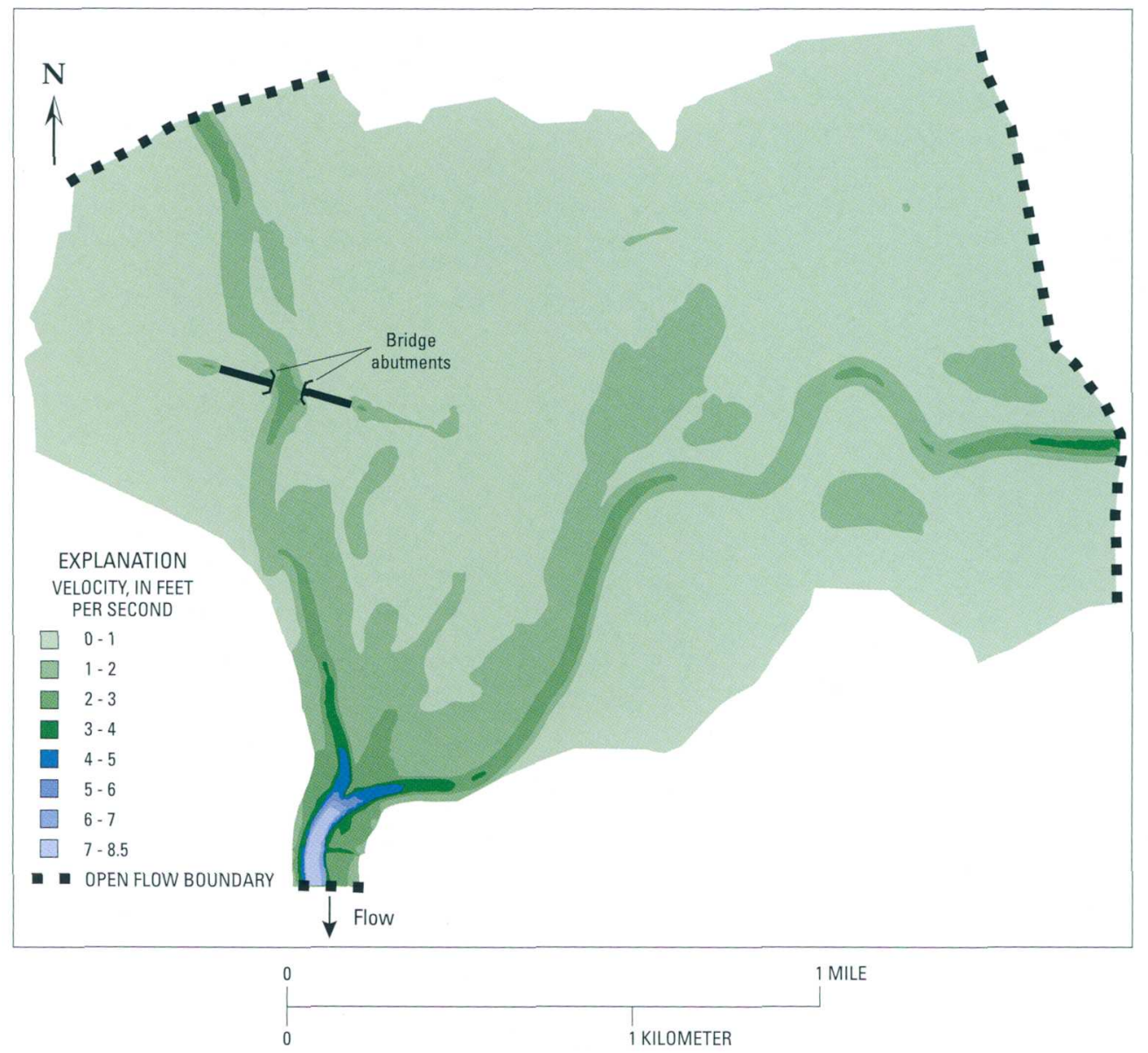

Figure 22. Computed velocity contours for 100 -year flood for existing conditions. 


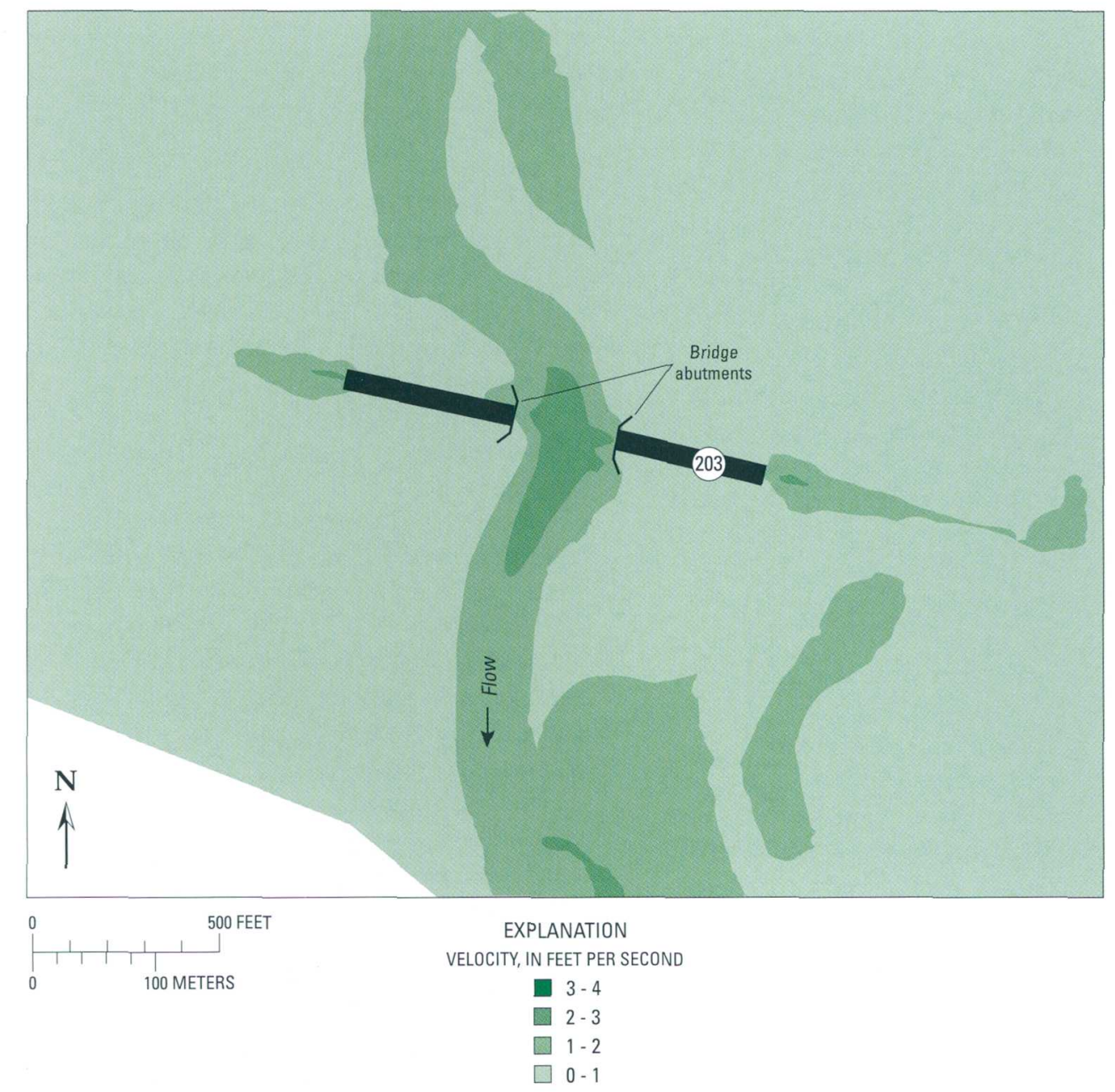

Figure 23. Computed velocity contours for 100-year flood for existing State Highway 203 bridge crossing.

\section{Proposed Conditions}

Simulation of floodflows for the 100-year flood at the gage for the proposed conditions indicated that 46.5 percent $\left(30,300 \mathrm{ft}^{3} / \mathrm{s}\right)$ of the peak flow was conveyed by the proposed bridge over Whitewater Creek,

46.9 percent $\left(30,500 \mathrm{ft}^{3} / \mathrm{s}\right)$ by the proposed main channel bridge over Pea River, and 6.6 percent $\left(4,300 \mathrm{ft}^{3} / \mathrm{s}\right)$ by the proposed relief bridge for Pea River. During this event, flow from Pea River $\left(3,990 \mathrm{ft}^{3} / \mathrm{s}\right)$ overtopped State Highway 125 and crossed over into the Whitewater Creek flood plain north of the proposed bypass. The watersurface elevation predicted at the downstream side of the proposed bridge over Whitewater Creek was $206.54 \mathrm{ft}$, whereas the water-surface elevation predicted at the downstream side of the proposed main channel bridge over Pea River was $206.63 \mathrm{ft}$. No overtopping of the proposed bypass occurred; however, U.S. Highway 84 was overtopped.

The maximum point velocities predicted for the proposed bypass bridges for the 100-year flood were $4.7 \mathrm{ft} / \mathrm{s}$ for the proposed Whitewater Creek bridge, $3.5 \mathrm{ft} / \mathrm{s}$ for the proposed main channel bridge over Pea River, and $2.8 \mathrm{ft} / \mathrm{s}$ for the proposed Pea River relief bridge. For the bridges mentioned above, average downstream and approach water-surface elevations were estimated by taking the average of the water-surface elevations at a group of nodes on a line at the location of interest. Approach elevations were selected from nodes about one bridge length upstream from the bridge. The average water-surface elevation about one bridge length 
upstream from the proposed Whitewater Creek bridge was about $1.2 \mathrm{ft}$ higher $(0.7 \mathrm{ft}$ due to levee modification and $0.5 \mathrm{ft}$ due to bypass) than that computed for the existing conditions.

For the proposed Pea River bridges, the approach elevation about one bridge length upstream from each bridge was about $1 \mathrm{ft}$ higher $(0.6 \mathrm{ft}$ due to levee modification and $0.4 \mathrm{ft}$ due to bypass) than that computed for the existing conditions. A complete tabulation of the hydraulic data for the 100-year flood for the bridges mentioned above is presented in tables 4 and 5. Computed water-surface elevations for the 100-year flood for the proposed conditions are shown in figure 24.

Corresponding velocity contours are shown in figure 25 . Computed velocity contours in the vicinity of the proposed Whitewater Creek Bridge are shown in figure 26. Computed velocity contours for the proposed Pea River bridges are shown in figure 27.

Table 4. Simulation of 100-year flood for existing conditions

[Input discharge $=63,500$ cubic feet per second $\left(\mathrm{ft}^{3} / \mathrm{s}\right)$; FESWMS, finite-element surface-water modeling system; ft, feet; Vmax, maximum point velocity in feet per second $(\mathrm{ft} / \mathrm{s}) ;-$, no data]

\begin{tabular}{|c|c|c|c|c|c|}
\hline Location & $\begin{array}{c}\text { FESWMS } \\
\text { discharge } \\
\left(\mathrm{ft}^{3} / \mathrm{s}\right)\end{array}$ & $\begin{array}{l}\text { Percent of } \\
\text { total } \\
\text { FESWMS } \\
\text { flow }\end{array}$ & $\begin{array}{l}\text { FESWMS } \\
\text { downstream } \\
\text { stage } \\
\text { (ft) }\end{array}$ & $\begin{array}{c}\text { FESWMS } \\
\text { upstream } \\
\text { stage } \\
\text { (ft) }\end{array}$ & $\begin{array}{c}\text { FESWMS } \\
V_{\max } \\
(\mathrm{ft} / \mathrm{s})\end{array}$ \\
\hline Whitewater Creek bridge & 15,600 & 24.6 & 205.60 & 205.76 & 2.8 \\
\hline State Highway 203 roadway & 15,300 & 24.1 & - & - & - \\
\hline $\begin{array}{l}\text { Pea River flood plain at approximate } \\
\text { location of bypass }\end{array}$ & $32,600^{\mathrm{a}}$ & 51.3 & 205.77 & 205.95 & - \\
\hline Total & $63,500^{b}$ & & & & \\
\hline
\end{tabular}

"Flow conveyed by the Pea River flood plain east of State Highway 125.

${ }^{b}$ Difference between total bridge discharge and total input discharge is due to small, local mass conservation errors (Lee and Froehlich, 1989).

Table 5. Simulation of 100-year flood for proposed conditions

[Input discharge $=63,500$ cubic feet per second $\left(\mathrm{ft}^{3} / \mathrm{s}\right)$; FESWMS, finite-element surface-water modeling system; ft, feet; $V \max$, maximum point velocity in feet per second $(\mathrm{ft} / \mathrm{s}) ;-$, no data]

\begin{tabular}{lccccc}
\hline \multicolumn{1}{c}{ Location } & $\begin{array}{c}\text { FESWMS } \\
\text { discharge } \\
\left(\mathbf{f t}^{\mathbf{3}} \mathbf{/ s}\right)\end{array}$ & $\begin{array}{c}\text { Percent of } \\
\text { total } \\
\text { FESWMS } \\
\text { flow }\end{array}$ & $\begin{array}{c}\text { FESWMS } \\
\text { downstream } \\
\text { stage } \\
\text { (ft) }\end{array}$ & $\begin{array}{c}\text { FESWMS } \\
\text { upstream } \\
\text { stage } \\
\text { (ft) }\end{array}$ & $\begin{array}{c}\text { FESWMS } \\
\text { Vmax } \\
(\mathbf{f t} / \mathbf{s})\end{array}$ \\
\hline Whitewater Creek bridge & 30,300 & 46.5 & 206.54 & 206.96 & 4.7 \\
Pea River main channel bridge & 30,500 & 46.9 & 206.63 & 207.00 & 3.5 \\
Pea River relief bridge & 4,300 & 6.6 & 206.65 & 207.00 & 2.8 \\
Total & $65,100^{\mathrm{a}}$ & & & & \\
\hline
\end{tabular}

"Difference between total bridge discharge and total input discharge is due to small, local mass conservation errors (Lee and Froehlich, 1989). 


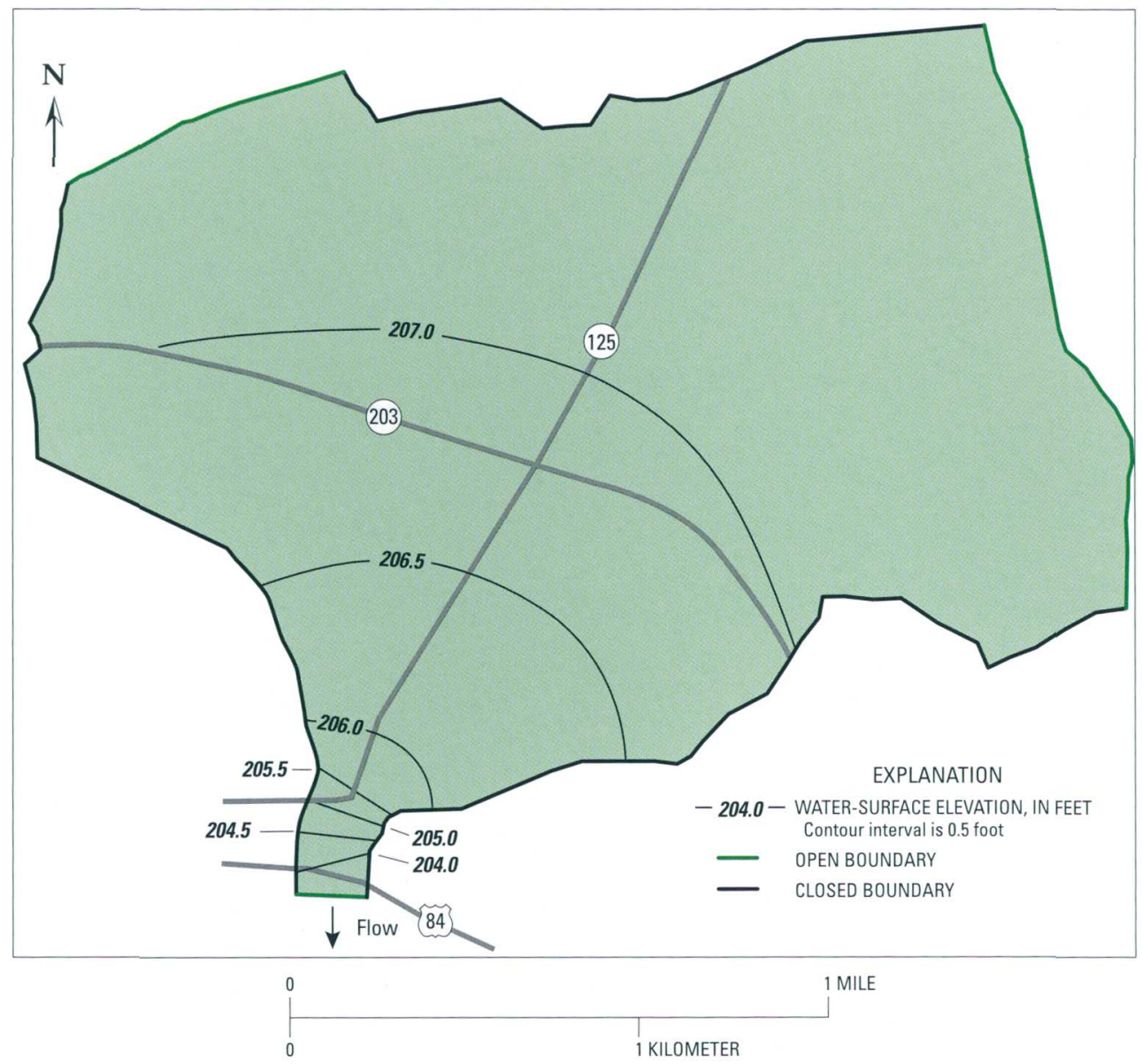

Figure 24. Computed water-surface elevations for 100-year flood for proposed conditions. 


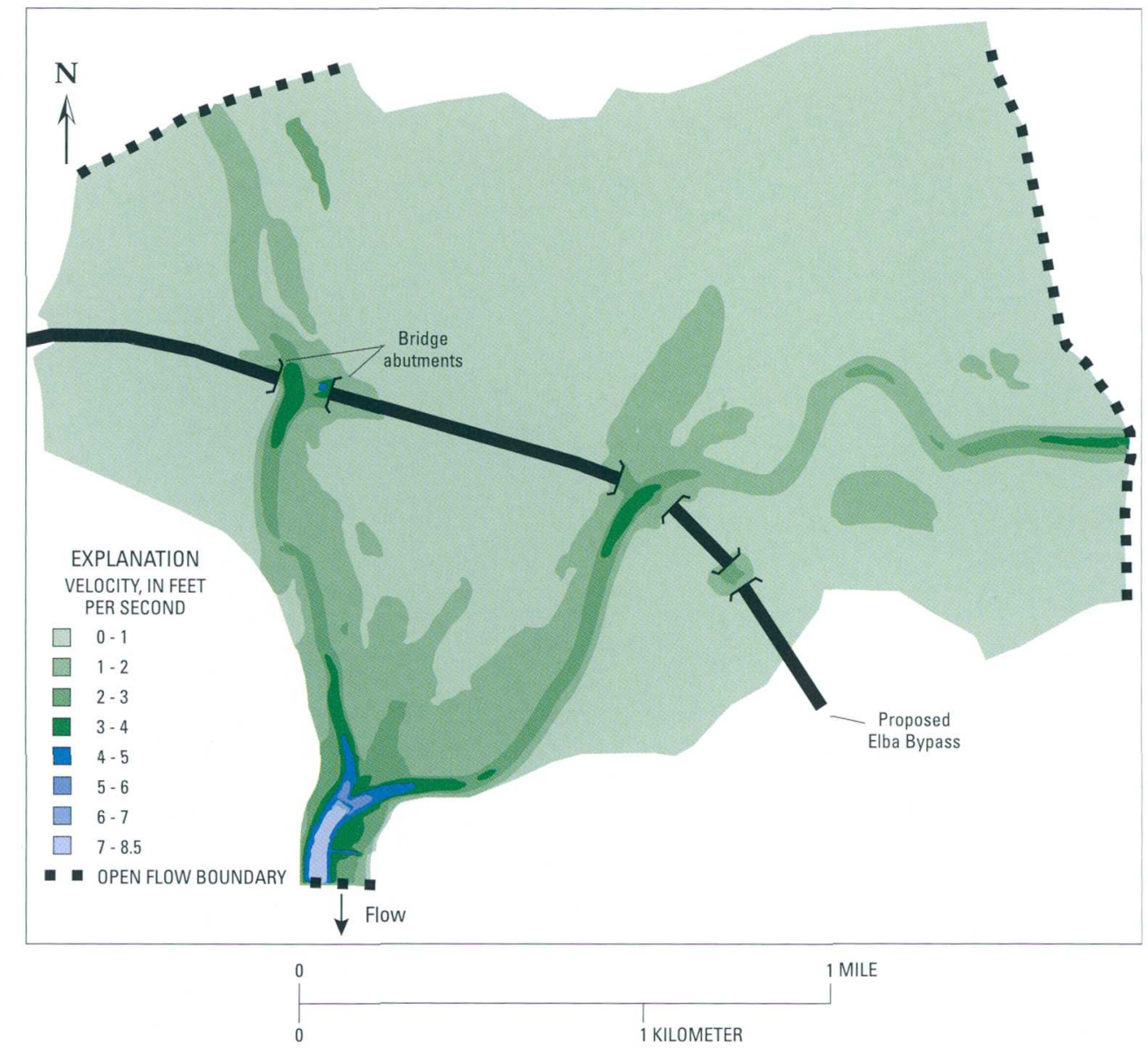

Figure 25. Computed velocity contours for 100-year flood for proposed conditions. 


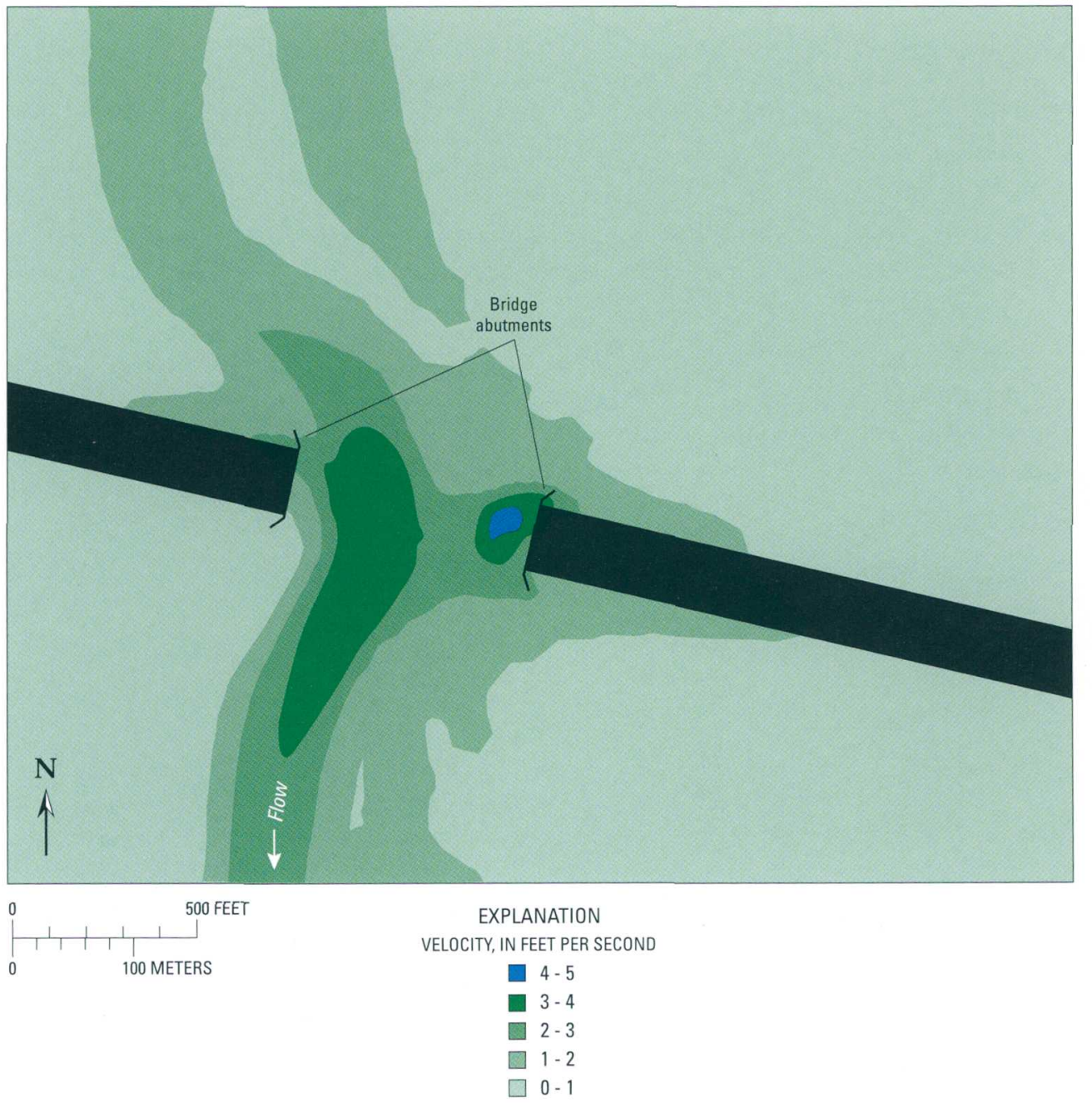

Figure 26. Computed velocity contours for 100-year flood for proposed bridge crossing of Whitewater Creek. 


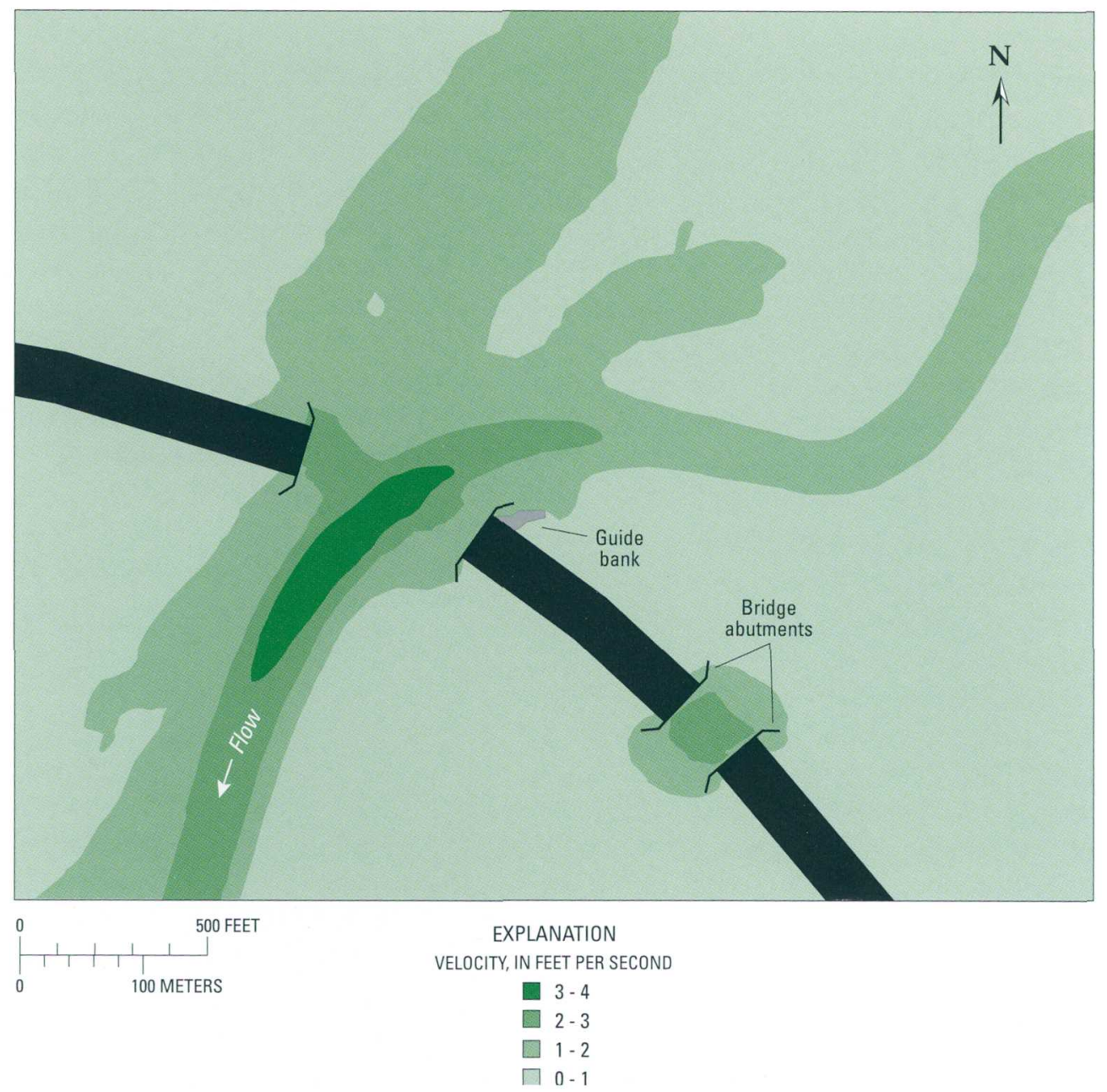

Figure 27. Computed velocity contours for 100-year flood for proposed bridge crossing of Pea River.

\section{SUMMARY}

A two-dimensional finite-element surface-water model was used to study the effects of the proposed modifications to the State Highway 203 corridor (proposed Elba Bypass) on water-surface elevations and flow distributions during flooding in the Pea River and Whitewater Creek Basins at Elba, Coffee County, Alabama. Flooding was first simulated for the March 17, 1990, flood, using the 1990 flood-plain conditions to calibrate the model to match measured data collected by the USGS and the USACE after the flood. After model calibration, the effects of flooding were simulated for four scenarios: (1) floods having the 50- and 100-year recurrence intervals for the existing flood-plain, bridge, highway, and levee conditions; (2) floods having the
50- and 100-year recurrence intervals for the existing flood-plain and levee conditions with the State Highway 203 embankment and bridge removed; (3) floods having the 50- and 100-year recurrence intervals for the existing flood-plain, bridge, and highway conditions with proposed modifications (elevating) to the levee; and (4) floods having the 50- and 100-year recurrence intervals for the proposed conditions reflecting the Elba Bypass and modified levee.

The simulation of floodflow for the Pea River and Whitewater Creek flood of March 17, 1990, in the study reach compared closely to flood profile data obtained after the flood. The flood of March 17, 1990, had an estimated peak discharge of $58,000 \mathrm{ft}^{3} / \mathrm{s}$ at the gage (just below the confluence of Pea River and Whitewater Creek), and was estimated to be between a 50-year and 
100 -year flood event. The estimated peak discharges were 40,000 and $42,000 \mathrm{ft}^{3} / \mathrm{s}$ for Pea River and Whitewater Creek, respectively.

Simulation of floodflows for the 50-year flood $\left(51,400 \mathrm{ft}^{3} / \mathrm{s}\right)$ at the gage for existing flood-plain, bridge, highway, and levee conditions indicated that about 31 percent of the peak flow was conveyed by the State Highway 203 bridge over Whitewater Creek, approximately 12 percent overtopped the State Highway 203 embankment, and about 57 percent was conveyed by the Pea River flood plain east of State Highway 125. For this simulation, flow from Pea River $\left(2,380 \mathrm{ft}^{3} / \mathrm{s}\right)$ overtopped State Highway 125 and crossed over into the Whitewater Creek flood plain north of State Highway 203, creating one common flood plain. The water-surface elevation estimated at the downstream side of the State Highway 203 bridge over Whitewater Creek was $202.82 \mathrm{ft}$.

For the 100 -year flood $\left(63,500 \mathrm{ft}^{3} / \mathrm{s}\right)$ at the gage, the simulation indicated that about 25 percent of the peak flow was conveyed by the State Highway 203 bridge over Whitewater Creek, approximately 24 percent overtopped the State Highway 203 embankment, and about 51 percent was conveyed by the Pea River flood plain east of State Highway 125. The existing levee adjacent to Whitewater Creek was overtopped by a flow of $3,200 \mathrm{ft}^{3} / \mathrm{s}$ during the 100 -year flood. During this event, flow from Pea River $\left(6,710 \mathrm{ft}^{3} / \mathrm{s}\right)$ overtopped State Highway 125 and crossed over into the Whitewater Creek flood plain north of State Highway 203. The watersurface elevation estimated at the downstream side of the State Highway 203 bridge over Whitewater Creek was $205.60 \mathrm{ft}$.

Simulation of floodflows for the 50-year flood at the gage for existing flood-plain and levee conditions, but with the State Highway 203 embankment and bridge removed, yielded a lower water-surface elevation (202.90 ft) upstream of this bridge than that computed for the existing conditions. For the 100-year flood, the simulation indicated that removing the State Highway 203 embankment and bridge lowered the upstream stage about $0.07 \mathrm{ft}$.

Simulation of floodflows for the 50-year flood at the gage for existing flood-plain, bridge, and highway conditions with proposed modifications (increased crest elevation) to the levee yielded the same water-surface elevations as those for the existing conditions. This is due to the fact that the 50-year flood did not overtop the existing levee and, therefore, would not overtop a taller one. For the 100-year flood, the simulation indicated that elevating the levee increased the upstream stage about $0.7 \mathrm{ft}$ in the vicinity of State Highway 203.
Simulation of floodflows for the 50-year flood at the gage for the proposed conditions indicated that about 43 percent of the peak flow was conveyed by the proposed bridge over Whitewater Creek, approximately 52 percent by the proposed main channel bridge over Pea River, and about 5 percent by the proposed relief bridge for Pea River. For this simulation, flow from Pea River $\left(1,220 \mathrm{ft}^{3} / \mathrm{s}\right)$ overtopped State Highway 125 and crossed over into the Whitewater Creek flood plain north of the proposed bypass. The water-surface elevation estimated at the downstream side of the proposed bridge over Whitewater Creek was $202.77 \mathrm{ft}$, whereas the watersurface elevation estimated at the downstream side of the proposed main channel bridge over Pea River was $203.06 \mathrm{ft}$. The average water-surface elevation about one bridge length upstream from the proposed Whitewater Creek bridge was about $0.04 \mathrm{ft}$ higher than that computed for the existing conditions. No overtopping of the proposed bypass occurred.

For the 100-year flood, the simulation indicated that about 46 percent of the peak flow was conveyed by the proposed bridge over Whitewater Creek, approximately 47 percent by the proposed main channel bridge over Pea River, and about 7 percent by the proposed relief bridge for Pea River. For this simulation, flow from Pea River $\left(3,990 \mathrm{ft}^{3} / \mathrm{s}\right)$ overtopped State Highway 125 and crossed over into the Whitewater Creek flood plain north of the proposed bypass. The watersurface elevation estimated at the downstream side of the proposed bridge over Whitewater Creek was $206.54 \mathrm{ft}$, whereas the water-surface elevation estimated at the downstream side of the proposed main channel bridge over Pea River was $206.63 \mathrm{ft}$. The average water-surface elevation about one bridge length upstream from the proposed Whitewater Creek bridge was about $1.2 \mathrm{ft}$ higher $(0.7 \mathrm{ft}$ due to levee modification and $0.5 \mathrm{ft}$ due to bypass) than that computed for the existing conditions. For the proposed Pea River bridges, the approach elevation about one bridge length upstream from each bridge was about $1 \mathrm{ft}$ higher $(0.6 \mathrm{ft}$ due to levee modification and $0.4 \mathrm{ft}$ due to bypass) than that computed for the existing conditions. No overtopping of the proposed bypass occurred.

\section{REFERENCES}

Atkins, J.B., 1996, Magnitude and frequency of floods in Alabama: U.S. Geological Survey Water-Resources Investigations Report 95-4199, 239 p.

Froehlich, D.C., 1989, Finite element surface-water modeling system-Two dimensional flow in a horizontal plain-Users manual: U.S. Department of Transportation, no. FHWA-RD-88-187, 285 p. 
Lee, J.K., and Froehlich, D.C., 1989, Two-dimensional finite-element hydraulic modeling of bridge crossings-Research report: U.S. Department of Transportation, no. FHWA-RD-88-146, 256 p.

Olin, D.A., 1988, Estimating flood hydrographs and volumes for Alabama streams, U.S. Geological Survey Water-Resources Investigations Report 88-4041, 25 p.
Pearman, J.L., Stricklin, V.E., and Psinakis, W.L., 2001, Water resources data, Alabama, Water year 2001: U.S. Geological Survey Water-Data Report AL-01-1, 669 p. Shearman, J.O., 1990, User's manual for WSPRO-A computer model for water surface profile computations: U.S. Department of Transportation, no. FHWA-IP-89027, $177 \mathrm{p}$. 
I

음

8

志

$\leq$

․ㅡㄹ.

₹윽

오금

守 응

근 윽

궁

믕옥

吕 0

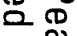

핌

远

四

잉

is a

क 5

$\stackrel{乛}{\longrightarrow}$

픔

D

$\unrhd \overrightarrow{\mathrm{D}}$

O

О

깅 즞

$\overline{5}$ 